\title{
LEVANTAMENTO POPULACIONAL DE BESOUROS COPRÓFAGOS (COLEOPTERA: SCARABAEIDAE) NO ESTADO DE AMAMBAY, REPÚBLICA DO PARAGUAI
}

MIGUEL ANGEL RUIZ DÍAZ VILLALBA

Engenheiro Agrônomo

Orientador: Prof. Dr. LUÍS CARLOS MARCHINI

Dissertação apresentada à Escola Superior de Agricultura "Luiz de Queiroz", Universidade de São Paulo, para obtenção do Título de Mestre em Ciências, Área de Concentração: Entomologia.

PIRACICABA

Estado de São Paulo - Brasil

Outubro - 2000 


\section{Dados Internacionais de Catalogaçāo na Publicaçāo (CIP) DIVISÃo DE BIBLIOTECA E DOCUMENTAÇÃO - Campus "Luiz de Queiroz"/USP}

Ruiz Díaz Villalba, Miguel Angel

Levantamento populacional de besouros coprófagos (Coleoptera: Scarabaeidae) no Estado de Amambay, República do Paraguai / Miguel Angel Ruiz Díaz Villalba. - -

Piracicaba, 2000.

$80 \mathrm{p}$.

Dissertação (mestrado) - - Escola Superior de Agricultura Luiz de Queiroz, 2000.

Bibliografia.

1. Besouro-coprófago 2. Controle biológico 3. Dinâmica populacional 4. Excremento de bovino 5. Fragmento florestal 6. Mosca-do-chifre 1. Título

CDD 632.7649 
Aos meus pais, Cantalicio e Eligia

por souberem me ensinar o caminho do honestidade

\section{DEDICO}

A minha esposa Sandra Elisabeth e a meus filhos Miguel (Jr.), Micaela e Milena, com muito amor e carinho,

\section{OFEREÇO}




\section{AGRADECIMENTOS}

- À Deus, por iluminar sempre meu caminho.

- À Universidade de São Paulo, através da Escola Superior de Agricultura "Luiz de Queiroz", pela oportunidade para realizar o curso de pósgraduação.

- Ao Dr. Luis Carlos Marchini, Professor do Departamento de Entomologia, Fitopatologia e Zoologia da ESALQ/USP, pela orientação, sincera amizade e constante apoio durante a realização do curso.

- A Faculdade de Ciências Agrarias, sede Pedro Juan Caballero, pela licença concedida.

- A Organização dos Estados Americanos (OEA), pela bolsa de estudos, sem a qual seria impossivel realizar esse sonho.

- Aos Professores do Curso de Pós-graduação em Entomologia do Departamento de Entomologia, Fitopatologia e Zoologia Agrícola da Escola Superior de Agricultura "Luiz de Queiroz", Universidade de São Paulo, pelos ensinamentos transmitidos durante o curso.

- Ao Dr. Sérgio Roberto Rodrigues, professor da Universidade Estadual de Mato Grosso do Sul e a Fernando Zagury Vaz-de Mello, do setor de Ecologia da Universidade Federal de Viçosa, pelo auxílio na identificação dos insetos coletados.

- Ao Prof. Dr. Sinval Siveira Neto, do Departamento de Entomologia, Fitoptologia e Zoologia Agrícola da Escola Superior de Agricultura, 
"Luiz de Queiroz", Universidade de São Paulo, pelo auxilio na leitura e sugestões muito valiosas na elaboração da dissertação

- A Jerson Guedes e Enrique Castiglione por saberem ser meus grandes amigos e especialmente ao primeiro por dedicar grande parte de seu tempo na leitura e correções da dissertação.

- A meus sogros Teódulo e Eulalia, pelo apoio e cuidados oferecidos a minha família, durante a prolongada ausência.

- Ao meu melhor amigo e colega Nestor C. Y. Kawata pelo apoio incondicional oferecido.

- Aos meus colegas do setor de Apicultura -ESALQ/USP, Itamar, Odinete, Alfredo, Gerbson, Patricia, Geni, Nilton, Augusta, Daniela e Vitor pela amizade e grande companheirismo demostrado.

- A meu irmão Edelmiro e esposa Aurora pelo seus constantes incentivos.

- A Gladys e Ramon, Delfina e Nestor, Virginia e Anibal (irmãs e cunhados), pela suas constantes preocupações pelo avanço do meu estudo.

- Ao Engenheiro Agrônomo Isabelino Lezcano pela sua colaboração na coleta dos insetos, sem a qual este trabalho seria impossivel.

- A Lencho, Kike e Osvaldo por ter-me oferecido a sua "república" para morar.

- A mia grande amiga Violeta Rojas pelo seu constante estimulo. 
- A meus colegas de pós-graduação da ESALQ/USP, pela convivência sempre proveitosa.

- A todos meus colegas da Faculdade de Ciências Agrarias, sede Pedro Juan Caballero e muito especialmente a Maria Celia e Ramón por seus constantes apoios.

- A Ana Alice por ser mais que uma conterrânea, uma verdadeira amiga.

- A todos que de alguma maneira contribuíram para concretizar este sonho. 


\section{SUMÁRIO}

Página

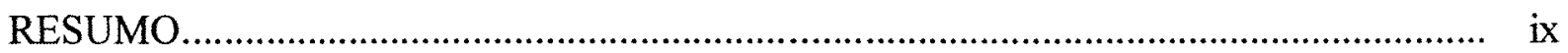

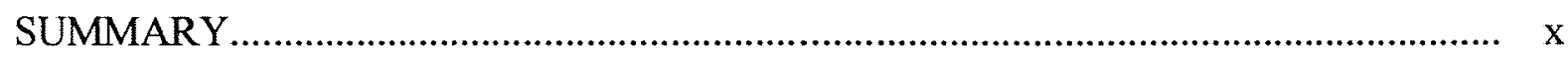

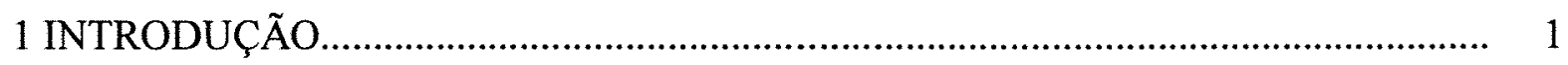

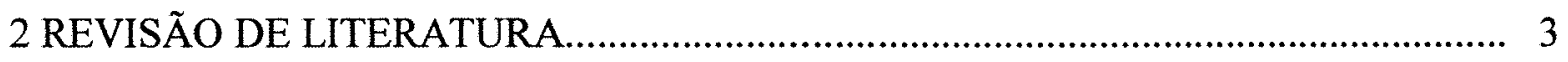

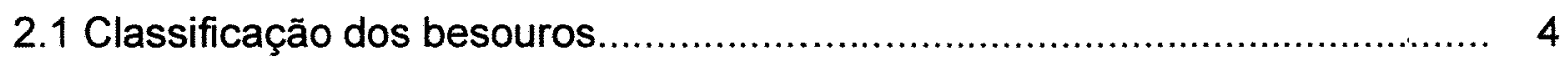

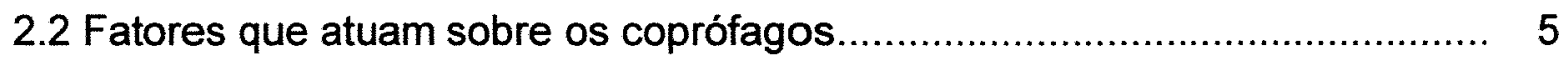

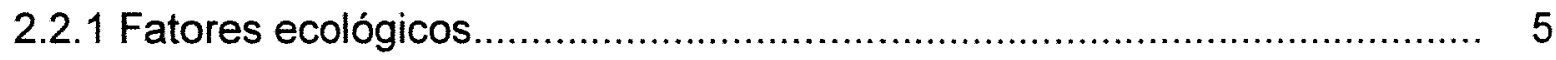

2.2.2 Efeitos da fragmentação florestal..................................................... 9

2.2.3 Qualidade de alimento.............................................................. 11

2.2.4 Uso de produtos químicos na pecuária............................................. 12

2.3 Aspetos biológicos e comportamentais............................................. 13

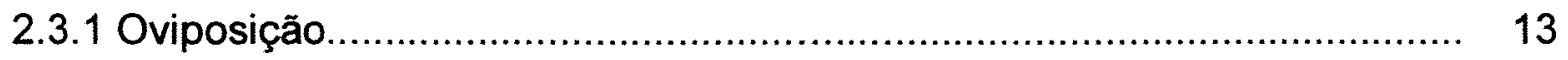

2.3.2 Localização do alimento........................................................... 15 
2.3.3 Comportamento sub-social.

2.4 Contribuições dos besouros coprófagos.

3 MATERIAL E MÉTODOS

3.1 Localização do experimento

3.2 Características das áreas de coletas.

3.3 Coleta de besouros coprófagos

3.4 Análise faunística dos dados obtidos

3.4.1 Índice de freqüência.

3.4.2 Constância

3.4.3 Dominância

3.4.5 Índice de diversidade.

3.4.6 Abundância.

3.4.7 Indice de similaridade (I)

3.4.8 Quociente de similaridade.

3.4.9 Percentagem de similaridade.

3.4.10 Índice de Sinantropia. 
4.1 Espécies coletadas.

4.1.1 Espécies na área de pastagem. 35

4.1.2 Espécies na área de mata. 39

4.1.3 Espécies na área semi-urbana. 44

4.2 Comportamento em relação aos fatores climáticos. 46

4.3 Caracterização das comunidades. 52

4.3.1 Índices de freqüência, abundância, constância, dominância

e diversidade.

52

4.3.1.1 Área de Pastagem. 52

4.3.1.2 Área semi-urbana. 53

4.3.1.3 Área de mata. 55

4.3.2 Indice de diversidade 57

4.3.3 Índice de similaridade. 57

4.4 Índice de sinantropia. 58

5 CONCLUSÕES 62 


\title{
LEVANTAMENTO POPULACIONAL DE BESOUROS COPRÓFAGOS NO ESTADO DE AMAMBAY, REPUBLICA DO PARAGUAI.
}

\author{
Autor: MIGUEL ANGEL RUIZ DIAZ VILLALBA \\ Orientador Prof. Dr. LUIS CARLOS MARCHINI
}

RESUMO

O conhecimento faunísticos dos escarabeídeos coprófagos associados às áreas de pastagem, semi-urbana e mata nativa no distrito de $P$. J. Caballero, a $510 \mathrm{~km}$ ao norte de Assunção e $22 \mathrm{~km}$ ao sul de P.J.Caballero, é precário. Com o objetivo de conhecer a dinâmica populacional desses insetos, foram colocadas em cada um dos locais, cinco armadilhas tipo "pitfall" iscadas com fezes de bovinos no período de 04-03-98 a 28-02-99. Os insetos eram coletados e as iscas trocadas semanalmente. A triagem do material foi realizada na ESALQ/USP, Piracicaba, SP e enviada a especialistas para sua identificação. Foram capturados 3.754 exemplares na mata, reunidos em 10 gêneros e 32 espécies, 2.238 indivíduos na pastagem pertencentes a 13 gêneros e 33 espécies, e 1.142 indivíduos na semi-urbana reunidos em 23 espécies e nove gêneros. Os indices de diversidade (Margalef), de Shannon-Weaner, de uniformidade e de Variância na mata foram 3,$7664 ; 2,1846 ; 0,6303 ; 0,0005$, respectivamente. Na pastagem, os Índices de diversidade (Margalef), de Shannon-Weaner, de uniformidade e de Variância foram 4,1487; 2,6442; 0,7562; 0.0004 , respectivamente. $\mathrm{Na}$ semi-urbana os Índices de diversidade (Margalef); de Shannon-Weaner; de uniformidade e o de Variância foram 3,$1248 ; 1,9288 ; 0,6151$; e 0,0014. respectivamente Nas 3 áreas nos meses mais quentes e chuvosos, foi coletado maior número de indivíduos e espécies em relação aos mais frios e secos. Tanto na mata, pastagem e semi-urbana os paracoprídeos foram dominantes com $44 \%, 51 \%$ e $48 \%$, respectivamente. 


\section{POPULATIONAL SURVEY OF DUNG BEETLES IN THE STATE OF AMAMBAY, REPUBLIC OF PARAGUAY}

\section{SUMMARY}

The knowledge about dung beetles associated to pasture, suburban areas and native forest of P. J. Caballero district (county), at $510 \mathrm{~km}$ north from Assunção and $22 \mathrm{~km}$ south from P.J.Caballero, is scarce (uncertain, deficient). With the objective of assessing the population dynamics of these insects, five pitfall traps baited with bovine feces were installed in both sites, during the 03-04-98 to 02-28-99 period. The baits were renewed and the insects collected weekly. The screening of the material was made at ESALQ/USP, Piracicaba, SP, Brazil, and sent to specialists for identification. Captures resulted in 3.754 specimens belonging to 10 genera and 32 species in the native forest; 2.238 specimens belonging to 13 genera and 33 species in the pasture and 1,142 specimens belonging to nine genera and 23 species in the suburban area. In the native forest the Margalef diversity index, the ShannonWeaner index, the uniformity index and the Variance index were 3.7664, 2.1846, 0.6303 and 0.0005 , respectively. In the pasture the Margalef diversity index, the Shannon-Weaner index, the uniformity index and the variance index were $4.1487,2.6442,0.7562$ and 0.0004 , respectively. In the suburban area the Margalef diversity index, the Shannon-Weaner index, the uniformity index and the Variance index were $3.1248,1.9288,0.6151$ and 0.0014 , respectively. In all the three areas the number of individuals and species collected in the warmer and rainy months, were higher than that collected in the colder and dry montths. Considering the three areas the paracoprid species were dominant: $44 \%$ (pasture), $51 \%$ (suburban) and $48 \%$ (native forest).

KEY WORDS: Insecta, Coleoptera, Dung Beetles, Population Index, Paraguay. 


\section{INTRODUÇÃO}

O Paraguai está situado no Hemisfério Sul do Continente Americano, entre os paralelos $19^{\circ} 18^{\prime}$ e $27^{\circ} 3^{\prime}$ de latitude Sul e entre os meridianos $54^{\circ} 15^{\prime}$ e $62^{\circ} 38^{\prime}$ Oeste de Greenwich. O trópico de Capricórnio passa no centro do seu território.

A principal atividade econômica do Paraguai está baseada na agropecuária e exploração florestal, sendo que a primeira é composta por cerca de 9.000 .000 cabeças de bovinos que representa uma importante fonte de divisas para o país e para as várias regiōes que desenvolvem essa atividade. Um dos exemplos é o município de Pedro Juan Caballero do Estado do Amambay, seja pela produção de alimentos como carne e leite, ou pela exploração de subprodutos como couro e outros derivados que apresentam grande interesse para as industrias em geral.

O estado de Amambay na atualidade conta com mais de 600.000 cabeças de bovino e a superfície destinada à agropecuária esta incrementando ano a ano. Na década de 80 , a área destinada à pecuária era de aproximadamente 400.000 ha ( $30,7 \%$ do estado) convertendo-se na atualidade em mais de 600.000 ha, ou seja, quase $50 \%$ da área do estado.

Existem vários fatores que interferem e limitam a atividade pecuária, dentre os quais, sem dúvida, estão incluídos os aspectos de sanidade animal, tais como: os carrapatos, helmintos e diversas espécies de moscas, que tradicionalmente estão associados à bovinocultura. A recente introdução da mosca-dos-chifres (Haematobia irritans), que atualmente ocupa toda a extensão 
do território paraguaio, tem causado sérias preocupações aos pecuaristas, devido aos conhecidos prejuizos que podem ocasionar.

Os danos ocasionados pela "mosca-dos-chifres" podem ser sérios, indo desde a irritabilidade do animal contribuindo para se alimentar menos, até torná-lo mais susceptivel a uma série de doenças e parasitoses, resultando em acentuada perda de peso e diminuição na produção; sua erradicação é praticamente impossivel, e o uso de produtos químicos apresenta uma série de restrições, indo desde resíduos tóxicos nos produtos de origem animal até a rápida aquisição de resistência pela mosca aos mesmos.

A fase jovem da "mosca-dos-chifres" e de muitas outras pragas, desenvolve-se nas massas fecais dos bovinos, e uma alternativa de controle seria o uso de besouros coprófagos que ocorrem nestes diferentes nichos ecológicos.

Os benefícios já conhecidos, proporcionados pelos coprófagos ao incorporar as massas fecais frescas são vários, entre eles pode-se citar a redução da população de moscas e de nematóides gastrointestinais, a reciclagem de nutrientes aumentando a fertilidade do solo e modificando a sua estrutura o que permite uma maior percolação das águas das chuvas, evitando dessa maneira a erosão.

O presente trabalho objetivou verificar as espécies de besouros coprófagos que ocorrem em área de pastagem, mata nativa e zona semiurbana na região de Pedro Juan Caballero; quais as principais espécies de besouros coprófagos responsáveis pela incorporação/desestruturação das massas fecais de bovinos em área de pastagem e as espécies que possam auxiliar no controle biológico da "mosca-dos-chifres" e outras pragas. 


\section{REVISÃO DE LITERATURA}

Os "vira-bostas" ou "rola-bostas" são besouros coprófagos conhecidos no mundo todo, derivando seu nome de uma característica específica: a coprofagia, isto é, seus alimentos principais são excrementos de animais, inclusive do homem (Hoffmann, 1998).

Os besouros coprófagos pertencem à família Scarabaeidae e Aphodiide, apresentam hábito alimentar muito variado, tendo como fonte de alimento fezes de animais domésticos, como ovelhas, suínos, cães e gatos, etc.; de animais selvagens, como leões, elefantes, girafas, antílopes, veados, rinocerontes, pássaros $e$ inclusive do homem, assim como também animais e plantas em decomposição, fungos, raízes, madeira, flores, folhas e ectoparasitos de mamíferos (Luederwaldt, 1914; Fincher et al., 1970; Rodrigues, 1989; Navarrete-Heredia \& Galindo, 1997; Hoffmann, 1998; Marchini, 1998).

Segundo Ratcliffe, citado por Fincher (1981) e Rodrigues (1985), estimase que existem mais de 30 mil espécies de besouros coprófagos no mundo. Só na subfamília Scarabaeinae, existem aproximadamente 200 gêneros com 6 mil espécies (Halffter, 1991), por sua vez, a família Aphodiidae está representada, em nível mundial, por cerca de 4 mil espécies (Dellasca, citado por Martínez, 1999).

Anduaga \& Halffter (1991) relataram a presença de coprófagos até nas madriguieras de roedores, e inclusive alguns, sendo inquilinos exclusivos, como 
Copris megasoma associada a Thomomys e Copris arizonensis associado com Neotoma. sp.

\subsection{Classificação dos besouros}

Devido às variações de comportamentos no modo como os besouros coprófagos trabalham a massa fecal para sua alimentação/oviposição, levaram vários pesquisadores a proporem divisões para estes, baseados unicamente na variação etológica. Assim os besouros são divididos em 3 grupos (Waterhouse, 1974; Heinrich \& Bartholomew, 1979; Doube 1988):

telecropídeos: neste grupo, os besouros apresentam o hábito de construir bolas de excrementos que são roladas para locais mais distantes das massas fecais e então são enterradas em galerias previamente construidas; são os típicos "rola-bostas".

paracoprídeos: estes são os besouros mais comuns, com cerca de $80 \%$ das espécies, caracterizando-se por construir galerias abaixo da massa fecal proximamente ou em profundidade que varia de 0,1 a 1,0 m, dependendo das condições do solo;

endocoprideos: os adultos penetram na massa fecal e aí permanecem, somente abandonando-a quando as condições ambientais forem desfavoráveis.

Por sua vez, Doube (1990), acrescenta a esses, um grupo adicional de coprófagos, os Kleptoparasitos: que apresentam o comportamento de furtar ou sustrair de outros coprófagos as "pêras de nidificação", para nelas colocarem seus ovos. 


\subsection{Fatores que atuam sobre os coprófagos}

\subsubsection{Fatores ecológicos}

De acordo com Halffter (1991) os fatores ecológicos e os diferentes microclimas verificados determinam a distribuição geográfica dos besouros coprófagos. Uma idéia a esse respeito é dada pelo mesmo autor, que verificou em uma pequena área da floresta tropical, da América do Sul, a presença de mais de 50 espécies, embora em toda a Europa e o Mediterrâneo contenham menos de 90 espécies, das quais 60 pertencem ao gênero Onthophagus.

De acordo com Terrom et al. (1991), ao estudarem a fauna dos coleópteros necrófilos, na biosfera "La Michilla", no México, encontraram maior abundância da família Scarabaeidae, cujos individuos representaram $81,3 \%$ do total das amostras, em relação aos outros insetos capturados.

Kirk (1992), encontrou 13 espécies para a provincia de Santa Cruz na Bolivia, das quais 9 pertencem à mata e só 4 espécies foram capturadas na pastagem.

$\mathrm{Na}$ Colômbia, Amat-Garcia (1999), relatou que existe um claro padrão de preferência por habitat, resumindo em 3 grupos, coprófagos de pastagem, de bordadura e interior de bosque.

$\mathrm{Na}$ Guatemala, Cano (1999), encontrou diferenças significativas na abundância e diversidade, entre habitats perturbados (área montanhosas e bosques vizinhos) e os bosques primários (alto e baixo), embora não tenham sido encontradas diferenças entre os bosques altos e baixos. Delgado (1999), obteve resultado semelhante em outra região da Colômbia ressaltando uma marcada diminuição dos besouros copro-necrófagos na medida em que aumenta o grau de perturbações dos ecossistemas naturais. 
No Paraguai, o único trabalho sobre as espécies de coleópteros, é o de Ruiz Díaz et al. (1995), onde identificou cerca de 60 espécies.

Em Aquidauana-MS, foi relatada a ocorrência de 20 espécies com ampla predominância do coprófago Onthophagus gazella (=Digitonthophagus gazella) introduzido pelo CNPGC-EMBRAPA, por ocasião do projeto para controle biológico da mosca-dos-chifres, e da espécie nativa Ontherus appendiculatus representando $49,2 \%$ e $20 \%$ da população, respectivamente (Flechtmann et al., 1996).

No Brasil, em diferentes levantamentos feitos para cada microclima, a diversidade de espécie encontrada foi desde $8 \mathrm{em}$ Jaraguá do Sul/SC (Flechtmann \& Rodriguez, 1995), 15 em Ilha Solteira/SP (Flechtmann et al., 1995), 43 espécies em Selvíria/MS (Rodrigues \& Flechtmann, 1993), 58 espécies em Manaus/AM (Klein, 1989); 18 espécies em Irati/PR (Rodrigues \& Flechtmann, 1995); 35 espécies em Pirassununga/SP, (Ruiz Díaz et al., 1998) e 97 espécies em Roraima (Vaz-de-Mello, 1999).

Na região dos Cerrados do Mato Grosso do Sul, Koller et al. (1997), relataram a captura de 9 espécies de coprófagos, com maior abundância de Ontherus sulcator $(30,41 \%)$ e Onthophagus gazella $(26,11 \%)$, seguida por Dichotomius nisus $(19,68 \%)$ e Ontherus appendiculatus $(17,24 \%)$. Já em Campo Grande MS, Koller et al. (1998), relataram a presença de 59 espécies de coprófagos com predominância de Dichotomius nisus, Ontherus sulcator, $D$. anaglypticus, Digitonthophagus gazella e Ontherus appendiculatus.

Para Minas Gerais, Vaz-de-Mello et al. (1999), citaram 22 gêneros e 95 espécies da familia Scarabaeidae.

Lobo et al. (1997), ao relatarem a diversidade de coprófagos no Parque Nacional de Huelva, Espanha, parte sul da Europa, encontraram aproximadamente 68 espécies. 
A subfamília Scarabaeinae é cosmopolita e exclusivamente coprófagos, sendo encontrada em ecossistemas com temperaturas altas. A diversidade diminui quando aumenta a distância das áreas neotropicais. Fora das áreas tropicais o número de espécies da subfamília Scarabaeinae, diminui consideravelmente e são substituídas por coprófagos de outras famílias, como os Aphodiidae e Geotrupidae (Halffter, 1991).

Segundo Halffter (1991), quase todas as espécies da subfamilia Scarabaeinae estão restritas às áreas com precipitação acima de $250 \mathrm{~mm}$ por ano e temperatura média anual acima dos $15^{\circ} \mathrm{C}$.

A ocorrência da família Aphodiidae é característica nas regiões temperadas do norte, embora exista em número substancial nas regiões subtropicais e tropicais (Hanski \& Cambefort, 1991).

Dudley (1979), ressaltou a importância do microclima onde se encontram as massas fecais, pois este tem influência na fauna de besouros coprófagos nelas encontrados.

Martínez \& Montes de Oca (1994), ao estudarem alguns fatores microambientais e o ciclo biológico das espécies coprófagos roladoras do gênero Canthon, verificaram que $C$. indigaceus chevrolati Harold e C. cyanellus cyanellus LeConte, apresentam hábitos diurnos nas zonas tropicais. Segundo Peck \& Forsyth (1982), atividades noturnas são caracteristicas de Ateuchus, Dichotomius e Eurysternus. Já a atividade diurna é característica dos gêneros Canthon e Oxysternon. As espécies Canthidium e Onthophagus têm atividade, tanto diurna como noturna. $O$ pico de atividade varia de espécie para espécie

A abundância de $C$. $i$. chevrolati foi favorecida por condições de alta temperatura, insolação direta e baixa umidade (áreas de pastagem). A abundância de C.c.cyanellus foi favorecida por temperaturas baixas e umidade alta (áreas de mata), ou quando o grau de insolação direta diminuiu (nas áreas 
de borda ou inclusive na periferia das áreas abertas), tendo então uma maior tolerância ecológica, constituindo-se dessa forma, numa espécie dominante nos locais de bordadura e podendo sobreviver ainda fora delas. As 2 espécies se reproduzem durante a estação chuvosa, que dura de 4 a cinco meses, entrando em diapausa durante a estação seca que dura aproximadamente 7 meses (Martinez \& Montes de Oca 1994).

Halffter \& Edmonds (1982), apontaram que a cobertura vegetal é um fator que tem grande efeito na distribuição dos coprófagos. Os autores afirmam que nas regiões tropicais é muito comum encontrar diferenças na composição das espécies em florestas alteradas ou não alteradas. Afirmam ainda que a variação da temperatura e a umidade do ar, a temperatura da superfície do solo, o grau da incidência direta dos raios solares, podem ter acentuada influência sobre a distribuição das espécies.

Fincher \& Hunter (1989), ao estudarem a influência da textura do solo sobre $D$. gazella e Onthophagus bonasus, encontraram maior emergência em solos que continham argila em relação ao arenoso evidenciando que a temperatura muito menor no sub-solo arenoso foi o fator que provocou a morte da maioria dos besouros, na fase de larvas, durante o inverno.

Um bom exemplo da influência externa na composição de espécies de uma região é dado por Ridsdill-Smith (1986), citando temperatura, precipitação pluvial, condições de solo e densidade de besouros como fatores influentes. Key (1982), relata que a altitude interfere na composição de espécies de um local. Neste contexto, Escobar (1999), verificou através do gradiente latitudinário, que grupos de espécies ficam restritas a certas categorias de altitude, com uma clara distinção de espécies entre os bosques abaixo de 1.250 metros sobre o nivel do mar ( $\mathrm{msnm}$ ), os de altura médias de 2000 ( $\mathrm{msnm}$ ) e os bosques situados acima desta elevação. Ele cita ainda que os valores referidos 
sobre a riqueza de espécies dos besouros coprófagos coincidiram com os resultados encontrados para plantas e aves.

Peck \& Forsyth, (1982) mencionaram que as densidades populacionais são altas e estáveis durante a transição de uma região úmida a outra região seca.

Nas condições da África do Sul, os adultos do telecoprídeo Kheper nigroaeneus, emergem na entrada da primavera com as primeiras chuvas de outubro ou novembro, ocasionalmente em setembro e podem ser coletadas somente depois de 1 a 2 semanas. No começo as fêmeas superam os machos na proporção de $3: 1$, para depois, devido aos cuidados que elas oferecem a seus descendentes, declinar nessa relação. A atividade reprodutiva termina no mês de fevereiro, para elas passarem o inverno embaixo da terra em diapausa (Edwards, 1988).

De acordo com Ruiz Díaz et al. (1999), uma mesma espécie pode apresentar alguma modificação com relação a seu horário de vôo para localização de alimento, quando presente em ambientes diferentes.

\subsubsection{Efeitos da fragmentação florestal}

Estudando besouros em florestas fragmentadas, Klein (1989), observou que ocorre menor riqueza de espécies coprófagas e maior número de espécies raras. A mudança de microclima após a fragmentação da floresta afeta as massas fecais e a população de besouros coprófagos. $O$ autor afirma ainda que existem diferenças na composição da comunidade dos besouros coprófagos, ao comparar fragmentos de uma área de 10 ha com uma floresta contínua. Mudanças na umidade e na temperatura promoveram importantes alterações no desenvolvimento e sobrevivência dos insetos, causando uma modificação na comunidade de besouros, relacionada às massas fecais. Esta alteração na comunidade de besouros por sua vez, pode aumentar a incidência de parasitos 
nos vertebrados. O mesmo autor complementa ainda, que além do clima afetar a incidência de insetos, a própria massa fecal pode ter sua atratividade aos besouros afetada, devido ao seu ressecamento e a perda de odor com o passar do tempo depois de excretada.

Bierregaard Jr. et al. (1992), afirmam também que as espécies que requerem grandes extensões florestais, não conseguem sobreviver em pequenos fragmentos e que o microclima nas bordaduras são modificados, alterando inclusive os padrões climáticos locais. Afirmam também que os efeitos fisicos e biológicos resultantes da fragmentação florestal são provavelmente pouco conhecidos, apesar de que certas modificações são fáceis de predizer, ao menos qualitativamente. De outro lado, Kirk (1992), afirma que nos locais onde a floresta é degradada os coprófagos estenotópicos desaparecem, produzindo uma diminuição na riqueza específica.

De acordo com Kruess \& Tscharntke (1994), a maior ameaça para a diversidade de insetos que atuam no controle biológico ocorre nas florestas fragmentadas, seja para uso na agricultura ou para a criação de gado. De acordo com o autor, o isolamento dos habitats fragmentados diminui o número de espécies, como também reduz os efeitos de inimigos naturais. Segundo Laurence et al. (1997), a perda da biomassa florestal é muito grande e pode alcançar até mais de $100 \mathrm{~m}$ a partir da bordadura dos bosques fragmentados, com uma perda de $36 \%$ da sua biomassa. Dentro de 10 a 17 anos depois da fragmentação, morrem árvores de grande porte, aumentando as mudanças microclimáticas e elevando a turbulência dos ventos, efeitos sumamente negativos para a maioria dos insetos, incluindo os coprófagos.

Rivera-Cervantes \& Garcia-Real (1998), encontraram em um bosque não queimado de pinus maior abundância dos escarabaeídeos (740) em relação a um bosque de pinus queimado ( 370 individuos). Verificaram também que as espécies dos gêneros Onthophagus sp. e Canthidium sp. apresentaram 
maior abundância no bosque de pinus queimado, o que poderia sugerir que sejam espécies indicadoras de perturbação.

Lopes et al. (1999), ao descreverem a reconstituição da comunidade de Scarabaeidae em áreas de regeneração da vegetação, encontraram que a composição de espécies é muito similar (maior que $75 \%$ de similaridade) entre os locais amostrados (herbáceo, herbáceo/arbustivo, arbustivo e arbóreo), sendo similar também à abundância, apresentando, entretanto, diferente padrão entre o número de espécies e a estrutura das guildas. $O$ ambiente herbáceo apresentou baixa riqueza de espécies alcançando um patamar de 15 espécies com a adição de arbustos à vegetação. A estrutura da guilda seguiu um padrão de diminuição da porcentagem de telecoprídeos e aumento de paracoprídeos com o aumento da complexidade do ambiente.

\subsubsection{Qualidade de alimento}

O alimento interfere no ciclo dos besouros coprófagos, como demostrado por Tyndale-Biscoe et al. (1981), em função da qualidade da massa fecal oferecida a estes. Essa assertiva coincide com a de Ridsdill-Smith (1986). Brussaard \& Visser (1987), observaram ainda que individuos maiores de Typheaus typheous eram oriundos de bolas de alimentação maiores oferecidas às suas larvas. Quando os recursos alimentícios dos besouros coprófagos são trocados, por exemplo, de esterco de carneiro para esterco de gado bovino, estes demostraram adquirir rapidamente um novo equilibrio, com drásticas mudanças na freqüência relativa em algumas espécies. Os endocoprideos, por exemplo, passam a ser dominantes, coexistindo com os grandes telecoprídeos, embora não significando mudanças na composição das espécies, mas incrementando-se tanto em número como em biomassa. 


\subsubsection{Uso de produtos químicos na pecuária}

Dentre os fatores que limitam o aumento populacional dos coprófagos, seja na fase larval, como adulta, encontra-se os produtos antiparasitários, muitas vezes, de uso indiscriminado. Esses produtos são utilizados para o tratamento dos animais contra os parasitos internos e externos que afetam o seu desenvolvimento (Pratissoli \& Braz Torres, 1998; Bianchin et al, 1998).

Galbiati et al. (1995) ao estudar os efeitos de vermífugos injetáveis em bovino de leite sobre Dichotomius anaglypticus (Mann, 1929), encontrou que na aplicação da dose de $1 \mathrm{ml} / \mathrm{kg}$ de peso vivo, houve maior incorporação do esterco no tratamento com Fosfato de Levamisol (Ripercoll), seguido por Doramectim (Dectomax); maior número de besouros mortos foram encontrados no tratamento com Dectomax, seguido por Ivermectim (Ivomex); aumento de $P$ no solo e maior número de pêras de alimentação foram encontrados em tratamentos de Ripercoll e Dectomax.

Ao estudar os efeitos de 12 inseticidas e carrapaticidas utilizadas no tratamento de bovinos, sobre o Onthophagus gazella, Bianchin et al. (1992), demostraram que os besouros em contato com as fezes de animais tratados com produtos "pour-on", em geral apresentaram alta mortalidade às $72 \mathrm{~h}$ após 0 contato, e que o produto Ivermectin (Ivomec) causou menor mortalidade de 0 . gazella. Em outro estudo similar (Bianchin et al. 1998), utilizando também 12 produtos de uso mais freqüentemente na bovinocultura brasileira, observaram que ocorreu mortalidade de besouros superior ao grupo de controle $(P<0,01)$ com todos os produtos utilizados até o $18^{\circ}$ dias depois da aplicação.

Estudos comparativos na Austrália estabeleceram que Moxidetin foi menos tóxico que Abamectina, ambos nas dosagens recomendadas usadas no primeiro ensaio, mas no segundo caso a Abamectina causou redução da população de besouros coprófagos em todas as concentrações; somando a 
estes as Avermectinas tiveram maior ação sobre as larvas e adultos jovens em relação aos adultos (Bulman et al. 1996).

\subsection{Aspetos biológicos e comportamentais}

Embora se encontrem muitas espécies de besouros identificadas no mundo, relativamente pouco é sabido sobre aspectos biológicos da maioria destes insetos. Sem dúvida, o hábito apresentado pelas espécies, de se enterrar no solo levando, tanto adultos como larvas, uma vida criptica, dificulta sobremaneira tais estudos. As variações encontradas de espécie para espécie são muitas grandes, não se podendo generalizar dados de biologia para os mesmos. No entanto, entre as espécies estudadas encontram-se Canthon indigaceus chevrolati Harold e Canthon cyanellus cyanellus LeConte, apresentando um ciclo biológico de aproximadamente 30 dias, com 3 a 4 gerações por ano ( Martínez \& Montes de Oca 1994).

$\mathrm{Na}$ Austrália Oriental, Tyndale-Biscoe et al. (1981), determinaram que para a espécie Onthophagus granulatus, a temperatura ótima para a produção de ninhos é de $25^{\circ} \mathrm{C}$, sendo o limite inferior de desenvolvimento $11,3^{\circ} \mathrm{C}$; para completar seu ciclo de ovo até adulto, são necessários 495 graus-dias e que a distribuição da espécie é determinada pelas chuvas de verão e pela temperatura.

\subsubsection{Oviposição}

A oviposição dos besouros coprófagos é variável em época e número de ovos, sendo no caso de Canthon lugubris, um ovo para cada pêra de nidificação (Myrcha \& Andrzejewska, 1984). No entando, há espécies que fazem a postura de grande número de ovos, como Onthophagus binodis, em que cada fêmea chega a pôr 50 ovos (Ridsdill-Smith, 1984). 
De acordo com Tyndale-Biscoe (1978), a taxa de oviposição aumenta com a temperatura entre 18 e $32^{\circ} \mathrm{C}$ e para a espécie Euoniticellus intermedius (Reiche) o limite é de $19,6^{\circ} \mathrm{C}$, que produz um ovo a cada 4 graus-dia acima deste limite, podendo cada fêmea colocar de 75 a 127 ovos.

Para Aphodius rufipes foi constatado que um grande número de indivíduos numa massa fecal ocasionam um decréscimo na taxa de oviposição (Holter, 1979).

A profundidade de enterramento das pêras de nidificação varia de acordo com a espécie, textura do solo, clima, entre outros fatores. Para Onitis caffer Bohemam, de acordo com Edwards (1986), por exemplo, a profundidade média de enterrio com umidade no solo é de $0,47 \pm 0,135 \mathrm{~m}$ no inverno chuvoso, $0,521 \pm 0,164 \mathrm{~m}$ no verão e varia de $0,166 \pm 0,59$ a $0,148 \pm 0,78 \mathrm{~m}$ com menor umidade.

Os ovos darão origem a larvas, que passam sempre por 3 instares (Halffter \& Mattews, 1966) e a maioria das espécies passa esta fase de desenvolvimento no solo, alimentando-se de bolas de massas fecais, construidas pela geração parental. $O$. binodis e $O$. alexis (Ridsdill-Smith et al., 1982) apresentam 2 gerações por ano, enquanto que Onthophagus ferox (Ridsdill-Smith, 1984) e Scarabaeus laticollis (Kirk \& Wallace, 1990) apresentam somente uma.

Dentre as espécies nativas do Brasil, a mais estudada foi Dichotomius anaglypticus. Nessa espécie cada fêmea põe de um a 2 ovos por ano, e a eclosão ocorre após 15 a 18 dias. A fase larval dá-se nas denominadas "pêras de alimentação" e essa fase dura em torno de 70 a 85 dias, a de pré-pupa 95 dias e da pupa, 85 dias. A espécie apresenta somente 1 geração por ano sendo a longevidade do adulto, em laboratório, de 100 dias (Alves, 1977; Alves \& Nakano, 1978). 


\subsubsection{Localização do alimento}

Uma característica biológica muito importante nos Scarabaeidae coprófagos é a velocidade com que estes encontram a massa fecal, após a mesma ter sido excretada. Halffter \& Matthews (1966), relatam que os coprófagos utilizam distintas "estratégias" para localizar o seu alimento. Alguns ficam sobre as folhas das plantas a certa altura esperando uma corrente de odor e outros voam em busca de uma pista.

Mohr (1943), considera que os Scarabaeidae são os primeiros a aparecer nas massas fecais, inclusive antes dos insetos predadores, o que é confirmado parcialmente por Hanski, (1980). Klein (1989), estima que a maioria destes ( 88 a $100 \%$ do total) chega na massa fecal nos 2 primeiros dias, e são os primeiros decompositores de fezes na comunidade florestal amazônica.

Na Dinamarca, Holter (1979), constatou que Aphodius rufipes coloniza a massa fecal quase imediatamente após a mesma ser excretada, permanecendo nesta por 4 a 6 dias. Massas fecais postas no inicio da noite tinham mais besouros que as colocadas na manhã do mesmo dia, evidenciando a importância do horário em que é depositada e indicando uma possível tendência de vôo noturno para esta a espécie. O autor relata que Ataechus e Dichotomius têm atividade de vôo noturna, enquanto que Onthophagus e Canthidium apresentam atividade diurna.

Os besouros coprófagos localizam o alimento em torno de um a cinco minutos após a deposição, sendo a velocidade de localização da massa fecal inversamente proporcional ao seu tamanho e a maneira de aproximação é diferente para cada gênero dependendo do comportamento de vôo de cada espécie (Peck \& Forsyth, 1982).

A localização da massa fecal pelos besouros coprófagos é efetivada através de estímulos olfativos, pousando normalmente a alguns metros da 
massa fecal e posteriormente caminhando em direção a esta (Mohr, 1943; Heinrich \& Bartholomew, 1979).

Alves (1977), verificou que Dichotomius anaglypticus é atraido à massa fecal por estímulos olfativos, fazendo vôos em círculo que diminui paulatinamente a distância até finalmente, pousar num ponto próximo a massa. O autor compara o pouso deste besouro como uma pequena queda livre, sendo a massa fecal geralmente não atingida. Após o pouso, o inseto dirige-se rapidamente em direção à massa introduzindo-se nesta.

Onthophagus voa em círculo direta e rapidamente na direção da fonte de alimento, para posteriormente mergulhar ou pousar perto da massa fecal a uns $0,20 \mathrm{~m}$ e logo caminhar na direção da fonte sendo que outros pousam diretamente nas fezes para iniciar imediatamente a enterrar as fezes. As espécies diurnas de Canthidium exibem um comportamento similar, mas seu vôo é menos direto, pois voam devagar, em zig-zags e em círculos, e freqüentemente ficam no solo, para logo em seguida iniciar a alimentação. Canthon angustatus voam a poucos centímetros de altura $(0,10-0,20 \mathrm{~m})$ sobre a massa fecal, fazendo zig-zags e em círculos, para logo pousar na fonte de alimento. Oxysternon, também se aproxima em zig-zag, passando muitas vezes acima da massa fecal. Freqüentemente batem na densa vegetação e grosseiramente caem no chão ou sobre o esterco, para iniciar imediatamente a atividade de alimentação (Peck \& Forsyth, 1982).

Para Aphodius, a massa fecal também é localizada pelo olfato, tornando-se durante a evolução adaptada a localizar as mais frescas. A dispersão destes não é somente entre massas fecais num pasto, podendo voar a $2.000 \mathrm{~m}$ de distância, e eventualmente a distâncias maiores. Vôos mais distantes são mais comuns nas espécies de maior biomassa que nas de menor biomassa (Hanski, 1980). 
Segundo Peck \& Forsyth (1982), Canthon angustatus, alguns Canthidium spp. e Onthophagus acuminatus, foram freqüentemente observados imóveis, sobre a folhagem a uma altura de um metro, aproximadamente. Freqüentemente ficam, presumivelmente buscando o odor, com as antenas abertas, que são os principais órgãos para detectar a fonte de alimento. Para as espécies maiores, como Oxysternom e Dichotomius foram observados voando na procura de seus alimentos, razão pela qual, são capturados a uma altura de um a 2 metros justamente acima da vegetação.

No Brasil os besouros coprófagos são encontrados em plena atividade logo após a entrada de animais na área de pastagem, no início de estação chuvosa (Rodrigues, 1985).

Para a maioria do gênero Coprini, a maior atividade de enterramento das massas fecais inicia-se 24 horas após a colonização (Doube et al., 1988).

Segundo Lumaret \& Kirk (1987), mesmo uma massa ressecada, normalmente não mais atrativa aos besouros coprófagos, pode voltar a tornarse atrativa se reumedecida. Outro comportamento que se pode destacar nos besouros coprófagos é a atividade de ficar pousado em locais diferentes a sua fonte de alimentação, principalmente sobre folhas e ramas das plantas. Dependendo das espécies consideradas, esse comportamento tem o propósito de escapar de seus predadores ou para a atividade de forrageamento e ainda, para termorregulação (Young, citado por Louzada, 1998).

Embora possa haver uma variação na ordem de chegada das espécies às massas fecais, essa colonização freqüentemente se dá por mais de um indivíduo da mesma espécie, como também por individuos de espécies distintas. De acordo com o tamanho da massa fecal, e/ou a quantidade de individuos presentes, pode ocorrer competição pelo alimento, influindo em alguns aspectos biológicos dos mesmos. A competição não se restringe apenas 
às espécies dentro da família Scarabaeidae, porém também com outros grupos taxonômicos, como larvas de dípteros, stafilinídeos, etc.

Ridsdill-Smith (1986), verificou redução no número de pêras de criação devido à competição intraespecífica, que é mais acentuada na primavera, bem como a competição interespécifica. Doube et al., (1988) afirmam ser a competição interespecifica mais acentuada na estação de temperatura mais o menos quente.

Guiller \& Doube (1989), verificaram uma correlação negativa entre a densidade de besouros numa massa fecal e a produção de bolas de nidificação. 4 casais de Onitis alexis por massa fecal foram suficientes para iniciar competição intraespecifica. Relacionaram também o tamanho dos besouros e a competição interespecifica, verificando que besouros menores são potencialmente mais vulneráveis a esta competição.

Segundo Miranda et al. (1990), numa criação da espécie D. gazella, pode ocorrer competição intraespecifica. Os autores verificaram que o máximo enterrio ocorreu com 7 casais. Quando aumenta o número de casais por balde, o enterrio e a formação de esferas de nidificação diminuíram. Mencionaram ainda, o alto potencial de incorporação dessa espécie, o que possibilitaria que uma massa fecal fosse totalmente incorporada em apenas 72 horas após a defecação do animal.

Favila (1988), para Canthon (C) cyanellus e Montes de Oca et al. (1991), para C. i. chevrolati Harold, verificaram que a competição intraespécifica ou a cooperação entre os indivíduos, depende do estado de maturação das gônadas tanto de machos quanto de fêmeas.

Rodrigues \& Flechtmann (1997), estudando os aspectos biológicos de Canthon lituratus (Germar) e Canthidium megathopoides Boucomont, 
observaram que existe competição intraespecifica no primeiro caso, e o segundo não apresentou competição, seja intra ou interespecífica.

Merritt \& Anderson (1977), ressaltaram a importância do fator biomassa da espécie no sucesso da ação dos besouros ao enterrar as massas fecais, sobrepondo-se mesmo ao número de individuos e refletindo assim na taxa de degradação da massa.

Os resultados obtidos por Roth (1993) e Guimarães \& Mendes (1998), no laboratório e no campo, mostraram que os besouros coprófagos podem ser incompativeis com outros agentes de controle biológico, como os estafilinídeos, já que causaram uma redução significativa na reprodução deste grupo. Estes insetos também atuam no controle biológico da mosca-dos-chifre, principalmente na fase de ovo ou nos primerios instares larvais.

\subsubsection{Comportamento sub-social}

Halffter \& Edmonds (1982), afirmam que a maioria dos coprófagos não exibe um comportamento sub-social. Freqüentemente o papel do casal é a provisão de alimento, geralmente na forma de esterco, colocando seus ovos e abandonando o ninho. Mas os autores relataram também, que algumas espécies apresentam um comportamento mais avançado nos cuidados da ninhada. Isto é, depois da fêmea colocar o ovo, ela fica próxima ao ninho para manutenção e proteção a seu descendente até emergir como adulto.

O comportamento sub-social dos besouros coprófagos é caracterizado pelo cuidado oferecido pelos pais a seus descendentes, depois da oviposição. O objetivo deste comportamento é de neutralizar as condições adversas às larvas, para permitir a sobrevivência de descendentes em maior porcentagem, entretanto gastando muito tempo e energia o que dificulta a produção de progênies adicionais. Esta perda na fecundidade é alternativa visando substancialmente aumentar a taxa de sobrevivência dos descendentes em 
relação a aqueles que não recebem esses cuidados (Tallamay \& Wood, 1984). Neste aspecto Huerta et al. (1981), mencionam que todas a espécies de Copris, conhecidas até agora, nidificam somente 1 vez na vida, com a exceção de $C$. remotus LeConte.

Halffter et al. (1996), resumem os resultados de suas próprias investigações e corrigem as suas conclusões anteriores, indicando que os cuidados parentais são estratégias muito efetivas, para permitir a sobrevivência dos descendentes. Os estudos indicam que a sobrevivência é muito superior em relação àquelas espécies que não mostram este tipo de comportamento. Os cuidados oferecidos pela fêmea incluem (1) a cobertura da superfície do ninho com solo e excremento, para prevenir a dessecação da pêra de nidificação, (2) reparação de fissuras na superficie do ninho e (3) proteção do ninho de fungos de solo, predadores e parasitas. Sucessivas observações realizadas por vários investigadores como Sato \& Inamori (1987); Edwards \& Aschenborn (1989); Klemperer (1993), confirmam este comportamento de cuidar de seus descendentes.

A espécie Copris diversus Waterhouse, segundo Tyndale-Biscoe (1984), apresenta-um comportamento desta natureza. Também Copris incertus Say, de acordo com Halffter et al. (1996), tem o estágio mais sensivel no ciclo biológico que vai da fase de pupa a adulto. Klemperer (1983), observou um comportamento similar para a espécie Oniticellus cinctus, mas esta espécie pode cuidar de vários ninhos ao mesmo tempo, podendo chegar a 20 o número de ninhos em cada câmara, ficando dentro por todo o tempo de desenvolvimento de seus descendentes, que dura aproximadamente um mês. O objetivo da permanência dentro da câmara é de reparar as pêras de nidificação ou repelir a presença de outras fêmeas da mesma espécie que possam atuar como kleptoparasitas. 


\subsection{Contribuições dos besouros coprófagos}

Os besouros coprófagos realizam um trabalho de extrema importância, tanto no combate de pragas que atacam os bovinos, quanto na reciclagem de matéria orgânica e mineral contidos nas massas fecais.

A rapidez e a eficiência no enterro dos excrementos bovinos asseguram o melhor aproveitamento dos seus constituintes e aumenta a atividade das minhocas e microorganismos presentes no solo que, em pouco tempo, tornam esses nutrientes novamente disponiveis para as plantas (Koller, 1998). Segundo esse autor, os besouros coprófagos, por alimentarem de fezes, constituem-se na maneira mais prática e economicamente viável que se dispõe, para reciclar as massas fecais de bovinos nas pastagens. Por sua vez, Waterhouse (1974), relatou o aumento da fertilidade do solo, melhoria da estrutura, da permeabilidade à água e melhoria da aeração, advindos da incorporação de massas fecais por besouros coprófagos.

Galbiati et al. (1995), ao compararem artificialmente os efeitos da incorporação entre $D$. anaglypticus e $O$. gazella, sobre pastagens, nas condições brasileiras, determinaram que maior incorporação do esterco ocorreu com casais de $D$. anaglypticus. $O$ tratamento com 4 casais de $D$. anaglypticus aumentou o teor de $\mathrm{P}, \mathrm{pH}, \mathrm{K}, \mathrm{Ca}, \mathrm{Mg}$, matéria orgânica e com 3 casais em $\mathrm{P}$, $\mathrm{pH}, \mathrm{K}$ e matéria orgânica. Também obtiveram maior diminuição de Al com casais de $D$. anaglypticus, sendo observadas maior altura e diâmetro de plantas em casais de $D$. anaglypticus e com 4 casais de $D$. gazella. $O$ peso e 0 comprimento das raizes foram maiores com 4 casais de 0 . gazella permanecendo esta espécie viva por um período maior.

Kirk (1992), relatou que a diminuição da atividade dos coprófagos nas florestas clareadas tem impacto sobre a estrutura do solo, sua fertilidade e sua capacidade de retenção da água da chuva, o que dificulta o restabelecimento da floresta. 
Os besouros coprófagos atuam também no controle de espécies ectoparasitos e endoparasitos de gado, que dependem das massas fecais para completarem seu ciclo de vida.

Fincher (1973), verificou que com o aumento da quantidade de besouros presentes na pastagem, ocorria a queda da população de larvas de nematóides gastrointestinais 14,7 vezes em relação ao local de onde foram retirados os coprófagos e 3,7 vezes em comparação ao local onde a população natural foi mantida. Segundo Bryan (1973), mesmo em número baixo, os besouros coprófagos reduzem o número de nematóides nas massas fecais, devido a aeração destas.

Estudando 3 áreas distintas (Fincher 1975), verificou que onde a população de besouros foi aumentada artificialmente, tinha 9 vezes menos larvas de helmintos no trato digestivo dos bovinos, em relação à área testemunha, sem besouros, havendo 2,7 vezes mais helmintos na área com população natural de besouros em relação ao local onde se aumentou a população.

$\mathrm{Na}$ Austrália, foi constatada a redução de $50 \%$ de helmintos gastrointestinais em massas fecais onde 0 . gazzella atuou por 3 dias, em comparação com a testemunha que após 8 dias, tinha 19 vezes mais helmintos (Bryan, 1976).

As moscas, alvo principal da maioria dos estudos com besouros coprófagos, podem também ter suas populações reduzidas pela ação besouros coprófagos. A população de mosca pode ser bastante reduzida, quando as fezes são ingeridas ou enterradas dentro de um a 2 dias após terem sido excretadas (Rodrigues, 1984).

Doube et al. (1988), trabalhando com Haematobia spp. na África verificaram, em condições de campo, uma mortalidade das larvas de moscas, 
de 84 a $98 \%$ e de $68 \%$ na Austrália, ocasionada por besouros coprófagos,. O tamanho da fêmea da mosca é diretamente proporcional à sua fecundidade desta, e os autores verificaram além da redução na população das moscas, uma redução no tamanho da cápsula cefálica dos adultos emergentes.

Além do controle na fase larval, a mosca pode ser controlada na fase de ovo, através do seu enterramento pelos besouros (Edwards \& Aschenborn, 1987).

Doube et al. (1988), observaram na África a mortalidade, ocasionada por besouros coprófagos, parasitos e predadores, da mosca nativa Haematobia thirouxi potans (Bezzi) na fase imatura e da introduzida na Austrália $H$. irritans exigua, provocando uma mortalidade de $97,6 \pm 2,1 \%$ em Pretoria, África. Também obtiveram mortalidades de $92,8 \pm 2,9 \%$ na pastagem e de $84,3 \pm 5,7 \%$ na área com vegetação em Hluhluwe, Sul de África. Na Austrália, a mortalidade foi significativamente menor que na África $(66,7 \pm 9,8 \%)$, atribuída principalmente às espécies de parasitos e predadores ausentes quando da introdução da praga no país.

Merrit \& Anderson (1977), obtiveram uma redução na densidade populacional de Haematobia irritans e M. autumnalis mesmo com a utilização de um besouro endocoprídeo de pequena biomassa (Aphodius fimetarius), aumentando artificialmente sua densidade populacional. Com o aumento da densidade populacional de $O$. binodis e $O$. alexis. Ridsdill-Smith \& Hayles (1990), obtiveram uma elevação significativa na mortalidade de larvas mais velhas de $M$. vetustissima. Ao comparar 2 áreas com diferentes populações de besouros coprófagos, Harris et al. (1982), encontraram uma relação inversa entre a quantidade de besouros capturados e a quantidade de larvas de moscas, atribuindo esse fato a atividade dos coprófagos.

Janzen (1982) e Shepherd \& Chapman (1998), destacam a importância ecológica dos coprófagos que contibuem para a dispersão das sementes e 
facilitam os seus escapes da predação por outros insetos ou roedores ao remover $e$ enterrar junto com 0 esterco as sementes nelas encontradas. Segundo Estrada \& Coates-Estrada (1991), 90\% das sementes de 28 espécies de plantas dispersas por macacos nas selvas Mexicanas são consumidas por roedores e que os coprófagos que as utilizam este recurso para sua alimentação-nidificacão, ajudam no escape das mesmas. Ao enterrar essas sementes a uma profundidade que vária de 0,025 a $0,12 \mathrm{~m}$, diminuem assim a eficácia com que os roedores encontram essas sementes. $O$ autor conclui que os besouros coprófagos são componentes importantes, não só na reciclagem de matéria e energia no ecossistema, mas também no processo de regeneração natural da mata. 


\section{MATERIAL E MÉTODOS}

\subsection{Localização do experimento}

O experimento foi conduzido em área de pastagem colonião (Panicum maximum), mata nativa e semi-urbana distante a $22 \mathrm{~km}$ ao sul de Pedro Juan Caballero, capital do Estado de Amambay, a $520 \mathrm{~km}$ ao Norte de Assunção, República do Paraguai, a uma altitude de $700 \mathrm{~m}$. O clima da região corresponde ao tipo cfa de Koeppen (mesotérmico) com uma temperatura média anual entre 21 e $23^{\circ} \mathrm{C}$ o que correspondem as mais baixas do país. A precipitação média anual esta entre 1.450 a 1.700 mm (UNA/FCA, Atlas de la Región Oriental del Paraguay, 1995).

\subsection{Características das áreas de coletas}

A superfície do estado tem 1.293 .300 ha, correspondente a $3,2 \%$ do pais, com uma população aproximada de 100.000 habitantes $(2,4 \%)$ do pais. O estado encontra-se situado geograficamente entre os paralelos $22^{\circ} 05^{\prime}-23^{\circ} 50^{\prime}$ latitude Sul e $55^{\circ} 28^{\prime}-57^{\circ} 00^{\prime}$ longitude Oeste. O solo predominante na área de coleta é do tipo Latossolo Vermelho-Escuro com Textura argilosa (Atlas de la Región Oriental del Paraguay, 1995).

A superfície da floresta atinge 442.390 ha (34,2\% da área do estado) sendo $70,8 \%$ de mata alta contínua, $20,9 \%$ de floresta alta degradada e de $8,2 \%$ de mata rala e isoladas. No periodo 1984-91 a devastação da floresta afetou 145.400 ha, o que provocou uma diminuição de 22.564 ha de mata alta contínua e 77.060 ha de mata alta degradada o que significa uma perda da biodiversidade de $3,6 \%$ anual em média. 
As armadilhas na mata, distanciadas $30 \mathrm{~m}$ uma da outra, foram instaladas em uma área protegida com uma superfície de aproximadamente 100 ha de mata alta contínua, pertencente à Universidade Nacional de Assunção, Faculdade de Ciências Agrárias. Dentre as principais espécies da floresta estão a Aspidosperma tormentosum, Protium heptaphyllum, Jacaratia corumbensis, Calophyllum brasiliense, Amburana cearensis, Myrocarpus frondosus, Cariniana estrellensis e Cedrela fissillis. Também encontram-se em grande quantidade as espécies Avherroidum paraguariensis, Sinaba glabra, Sinaba trichiloides, Turnera dolichostigma, Callisthene hassleri, Vochysia cinnamonea, Pterogyne nitens, Enterolobium contortisiliquum, llex paraguariensis, Pithecellobium saman e Balfourodendrom riedelianum.

A área semi-urbana caracteriza-se por um conjunto de 7 casas com instalações elétricas, distanciadas a aproximadamente $40 \mathrm{~m}$ uma da outra, com presença humana em forma permanente. As armadilhas foram colocadas no meio dessas casas, de modo que seja influenciada pela presença constante de pessoas.

As armadilhas na área de pastagem, contíguo a área da floresta, foram instaladas a uma distância de $40 \mathrm{~m}$ uma da outra, com uma superfície de 500 ha coberta por pasto implantado do tipo "colonião", Panicum maximum.

\subsection{Coleta de besouros coprófagos}

Para se verificar as espécies de besouros coprófagos nativos ocorrentes em áreas de pastagem, mata nativa e semi-urbana, bem como avaliar sua flutuação populacional e correlacionar com fatores climáticos, foram utilizadas cinco armadilhas tipo "pitfall" iscadas com massa fecal de bovinos em cada local de coleta. 
O uso de armadilhas tipo "pitfall" tem sido empregada em estudos, onde se avalia a distribuição e comportamento populacional de besouros coprófagos (Rodrigues \& Flechtmann, 1993; Rodrigues \& Marchini, 1996).

A armadilha tipo "pitfall" consistiu de um tripé de metal com cerca de 28 $\mathrm{cm}$ de altura, ao qual dependurou-se um volume de cerca de $500 \mathrm{ml}$ de massa fresca de bovino, envolta em voal. Imediatamente sob a massa estão dois copos plásticos de $500 \mathrm{ml}$ de volume, enterrados ao nivel do solo, uns destes preenchido com água e detergente.

Passados 7 dias da instalação das armadilhas, foram realizados as coletas dos insetos e imediatamente reinstaladas as armadilhas. O período de coleta durou um ano, de 03 de Março a 28 de Fevereiro de 1999. No Departamento de Entomologia da Universidade de São Paulo (ESALQ/USP), em Piracicaba/SP foram realizadas a triagem, codificação e montagem dos insetos coletados.

Os espécimes codificados e montados foram enviados aos especialistas em besouros coprófagos, Dr. Sérgio Roberto Rodrigues, professor da Universidade Estadual de Mato Grosso de Sul e Fernando Zagury Vaz-de-Mello, da Universidade Federal de Viçosa, para a sua identificação.

Os espécimes identificados foram depositados no Museu de Insetos Úteis da Escola Superior de Agricultura "Luiz de Queiroz" USP e no Departamento de Proteção Vegetal da Faculdade de Ciências Agrárias sede Pedro Juan Caballero no Paraguai

\subsection{Análise faunística dos dados obtidos}

Após a coleta dos insetos e tabulação dos dados obtidos nas distintas áreas experimentais foram calculados os indices faunísticos. Os índices utilizados foram os de freqüência, constância, diversidade (Margalef e Shannon e Wiener), abundância, similaridade e dominância. Os cálculos destes fatores foram 
determinados com a utilização do programa informatizado denominado ANAFAU (Análise Faunística), desenvolvida pela ESALQ/USP. Também foi calculado o quociente de similaridade e índice de sinantrópia, este último visando observar o grau de adaptação de certas espécies à presença humana.

3.4.1 Índice de freqüência $(f)$ das espécies foi determinado pela participação percentual do número de individuos de cada espécie em relação ao total coletado (Silveira Neto et al., 1976), estabelecendo-se classes de freqüência para cada espécie, como foi determinado por Fazolin (1991), adotando-se as seguintes categorias:

Muito Freqüente (MF),

Freqüente $(F)$,

Pouco Freqüente (PF),

\subsubsection{Constância}

A constância é calculada por meio de percentagem de ocorrência das espécies no levantamento de acordo com o estabelecido por Silveira Neto et al. (1976), e as espécies foram separadas nas seguintes categorias:

Espécies Constantes (W), presentes em mais de $50 \%$ das coletas;

Espécies Acessórias ( $Y$ ), presentes em 25-50\% das coletas;

Espécies Acidentais ( $Z$ ), presentes em menos de $25 \%$ das coletas.

\subsubsection{Dominância}

É a ação exercida pelos organismos dominantes. A dominância consiste na capacidade da espécie em modificar, em seu benefício, o impacto recebido do ambiente, podendo assim causar o aparecimento ou desaparecimento de outros organismos. É uma característica dificil de ser avaliada quantitativamente, pois 
depende de atividade desempenhada pela espécie na comunidade. As espécies foram classificadas em dominantes e não dominantes pelo método de Laroca e Mielke (1975).

\subsection{5 Índice de diversidade}

Diferentes índices expressam a diversidade de uma área ou região, explorando de forma diferente os componentes da diversidade. Assim vários índices têm sido propostos para caracterizar isoladamente a abundância de espécies e a eqüitabilidade de uma comunidade. Outros tipos de índices combinam as duas caracteristicas em um só valor e são conhecidos como índice de diversidade.

A utilização desses índices permite a comparação entre comunidades, independente do processo de levantamento e do tamanho da amostra. O cálculo da diversidade foi feito através do uso da fórmula proposta por Margalef em 1951.

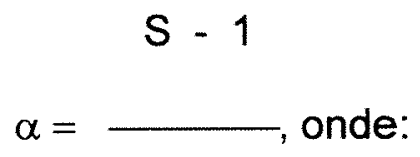

LN

S - número de espécies de cada local

LN - logaritmo neperiano do número de indivíduos do local.

Também foi calculado o Índice de diversidade $H^{\prime}$ (Shannon e Wiener)

$$
H^{\prime}=-\Sigma p_{i}\left(\ln p_{i}\right)
$$

onde,

$H^{\prime}=$ componente de riqueza de espécies; 
$p_{i}=$ frequencia relativa de espécie $i$ dada por $n / N$;

$\mathrm{n}_{i}=$ número de indivíduos da espécie $i$,

$\mathrm{N}$ = número total de indivíduos;

In = logaritmo neperiano.

O indice $H^{\prime}$ é um dos melhores índices para uso em comparações de comunidades, caso não haja interesse em separar os dois componentes da diversidade, abundancia e eqüitabilidade (Odum, 1988). Esse índice apresenta a vantagem de ser relativamente independente do tamanho da amostra, o que permite a comparação entre comunidades ainda que as amostragens em cada ambiente tenham sido realizadas com tamanhos diferentes.

\subsubsection{Abundância}

Refere-se ao número de indivíduos por unidade de superficie ou volume e varia no espaço (de uma comunidade para outra) e no tempo (flutuações populacionais). Para estimar a abundância de espécies nas áreas de coleta adotou-se as seguintes classes categorias:

- rara (r),

- dispersa (d),

- comum (c),

- abundante (a),

- muito abundante $(m)$, 


\subsection{7 Índice de similaridade (I)}

O índice de similaridade foi proposto para indicar a semelhança entre duas comunidades, com relação à composição de suas espécies

A fórmula utilizada para o cálculo foi a de Mountford (1962),

$$
l_{1}=\frac{2 j}{2 a b-(a+b) j} \text {, onde; }
$$

a - número de espécies na comunidade $A$

b - número de espécies na comunidade $B$

j - número de espécies comuns às comunidades $A$ e $B$

\subsubsection{Quociente de similaridade.}

Proposto para indicar a semelhança entre duas comunidades, em termos de composição de espécies. A fórmula para o cálculo é de Sorensen (1948), onde as letras tem o mesmo significado que na fórmula anterior:

\section{2j}

QS =

$$
a+b
$$

\subsubsection{Percentagem de similaridade}

É calculada pela somatória de menores valores da percentagem do total de individuos quando se comparam duas comunidades:

$$
\% S=\min (a, b, \ldots x)
$$




\subsubsection{0 Índice de Sinantropia.}

O Índice de Sinantropia (IS), para cada espécie, foi calculado pela fórmula de Nuorteva (1963), utilizada por muitos autores, principalmente para verificar a adaptação de moscas ao ambiente humano, mas neste caso para comprovar o grau de adaptabilidade dos besouros coprófagos à presença do homem.

$$
I S=-\frac{2 a+b-2 c}{\text {, onde }}
$$

$a=$ percentagem de uma determinada espécie coletada na zona semi-urbana em relação a esta mesma espécie, coletada na zona pastagem e zona de mata.

$$
\begin{aligned}
& b=\text { percentagem da mesma espécie coletada na área de pastagem } \\
& c=\text { percentagem da mesma espécie coletada na zona de mata. }
\end{aligned}
$$

Para a determinação deste índice, portanto, foram necessárias coletas em três ambientes ecológicos distintos. O indice varia de +100 a -100 , onde os valores positivos indicam maior associação das espécies com o ambiente humano e os valores negativos, intolerância a presença do homem em forma permanente.

\subsection{Dados meteorológicos}

Os dados meteorológicos foram obtidos a través da estação Hidrometeorológica do Aeroporto da cidade de Pedro Juan Caballero, distantes a três $\mathrm{km}$ do local da condução do experimento. Foram utilizadas as médias mensais de temperatura e precipitação pluvial, durante o periodo de condução do experimento.

Os dados de temperatura abrangeram as médias mensais de: 
- TMAX: temperatura máxima média $\left({ }^{\circ} \mathrm{C}\right)$;

- TMED: temperatura média $\left({ }^{\circ} \mathrm{C}\right)$;

- TMIN: temperatura mínima $\left({ }^{\circ} \mathrm{C}\right)$.

Para a precipitação pluvial, foi usado:

-PPT: a precipitação pluvial acumulada mensal em $\mathrm{mm}$. 


\section{RESULTADOS E DISCUSSÃO}

\subsection{Espécies coletadas}

A comunidade dos coprófagos, nas 3 áreas de coleta, está representada por 44 espécies, 13 gêneros, 9 tribos, 3 subfamílias e 2 famílias com um total de 7.134 indivíduos (Tabela 1).

Tabela 1 Espécies de coprófagos coletados em armadilhas "pitfall" iscadas com fezes de bovinos, no período de 04-03-98 a 28-02-99, em Pedro Juan Caballero-Paraguai.

\begin{tabular}{|c|c|c|}
\hline A- Família Scarabaeidae & Tribo Ateuchini & Tribo Eurysternini \\
\hline A-1 Subfam. Scarabaeinae & Canthidium aff. barbacenicum ${ }^{1}$ & Eurysternus caribaeus ${ }^{1}$ \\
\hline Tribo Onthophagini & Canthidium breve ${ }^{1}$ & Eurysternus paralellus ${ }^{1}$ \\
\hline Onthophagus aff. bucculus ${ }^{2}$ & Canthidium megathopoides ${ }^{1}$ & Eurysternus plebejus ${ }^{1}$ \\
\hline Onthophagus ranunculus ${ }^{2}$ & Trichillum externepunctatum ${ }^{1}$ & Tribo Gromphini \\
\hline Onthophagus hirculus ${ }^{2}$ & Tribo Coprini & Gromphas lacordairei $^{2}$ \\
\hline Digitonthophagus gazella ${ }^{2}$ & Ontherus sulcator ${ }^{2}$ & B- Familia Aphodiidae \\
\hline Onthophagus sp. $1^{2}$ & Ontherus appendiculatus ${ }^{2}$ & B-1 Subfam. Eupariinae \\
\hline Onthophagus sp. $2^{2}$ & Ontherus sp. ${ }^{2}$ & Tribo Eupariini \\
\hline Onthophagus sp. $3^{2}$ & Dichotomius nisus $^{2}$ & Ataenius sp. $1^{1}$ \\
\hline Tribo Canthonini & Dichotomius bos ${ }^{2}$ & Ataenius scuptor ${ }^{1}$ \\
\hline Canthon quinquemaculatus ${ }^{3}$ & Dichotomius carbonarius $^{2}$ & Ataenius sp. $2^{1}$ \\
\hline Canthon aff. curvodilataus ${ }^{3}$ & Dichotomius ascanius $^{2}$ & Ataenius sp. ${ }^{1}$ \\
\hline Canthon aff. paraguayanum ${ }^{3}$ & Dichotomius mormom $^{2}$ & Cartwrightia cartwrighti $^{1}$ \\
\hline Canthon lituratus $^{3}$ & Dichotomius sp. $1^{2}$ & B-2 Subfam. Aphodiinae \\
\hline Canthon septemmaculatus ${ }^{3}$ & Dichotomius sp. $2^{2}$ & Tribo Aphodiini \\
\hline Canthon Iuctuosum ${ }^{3}$ & Diabroctis mimas ${ }^{2}$ & Aphodius lividus ${ }^{1}$ \\
\hline Canthom sp. ${ }^{3}$ & Tribo Phanaenini & Aphodius nigrita ${ }^{1}$ \\
\hline \multirow[t]{2}{*}{ Delthochilum sp. ${ }^{3}$} & Coprophaneus jasius ${ }^{2}$ & Aphodius sp. ${ }^{1}$ \\
\hline & Coprophaneus horus $^{2}$ & \\
\hline
\end{tabular}

Endocoprídeo'. Paracoprideo ${ }^{2}$. Telecoprídeo ${ }^{3}$. 
Considerando o hábito de alimentação e nidificação dos besouros coprófagos estudado por Waterhouse (1974), verificou-se a presença dos 3 grupos de insetos (paracoprídeo, telecoprídeo e endocoprídeo), cuja classificação percentual observada na presente pesquisa, encontra-se na Figura 1, sendo $47,70 \%$ de paracoprídeo, $34,10 \%$ de endocoprídeo e $18,10 \%$ de telecoprídeo, similar ao encontrado por Lopes et al. (1999). Os autores verificaram uma percentagem menor dos telecoprídeos, em relação aos paracoprídeos ao descrever a reconstituição de besouros coprófagos em áreas de regeneração da vegetação.

\section{$\square$ Paracoprídeo $\square$ Endocoprídeo $\square$ Telecoprídeo}

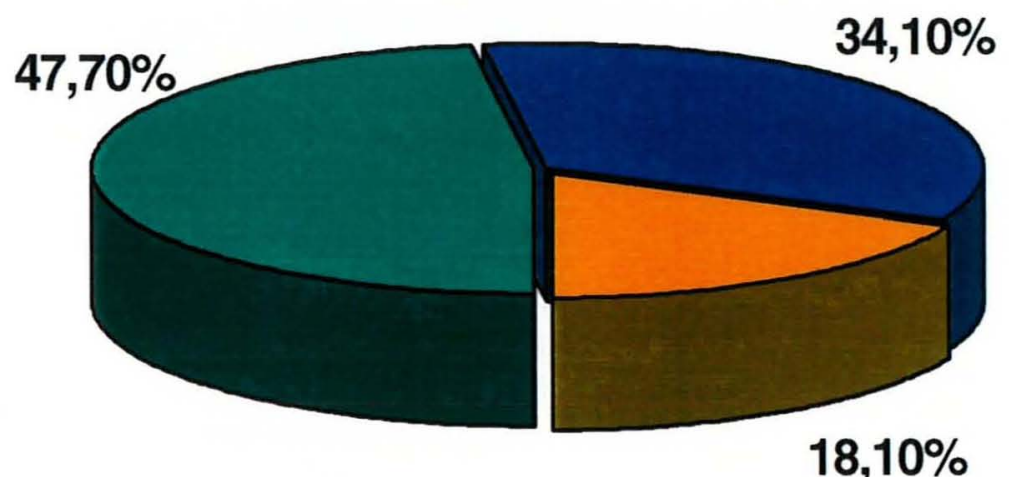

Figura 1 Coprófagos coletados nas 3 áreas com armadilhas "pitfall" iscadas com fezes de bovinos, no período de 04-03-98 a 28-02-99, em Pedro Juan Caballero-Paraguai.

\subsubsection{Espécies na área de pastagem}

$\mathrm{Na}$ área de pastagem foram coletados 33 espécies, sendo 1 a mais em relação à mata (32 espécies); em referencia a números absolutos, foram capturados 2.238 indivíduos sendo em menor número que na área de mata com 3.778 indivíduos (Tabela 2). 
Tabela 2. Total de indivíduos e número de espécies coletadas mensalmente com armadilhas "pitfall" iscadas com fezes de bovinos, em área de pastagem, no período de 04-0398 a 20-02-99, em Pedro Juan Caballero-Paraguai.

\begin{tabular}{|c|c|c|c|c|c|c|c|c|c|c|c|c|c|c|}
\hline & Espécies & M & A & $\mathbf{M}$ & $\mathrm{J}$ & $\mathrm{J}$ & A & $s$ & 0 & $\mathbf{N}$ & D & $\mathrm{J}$ & $F$ & Tot \\
\hline $1-$ & Ataenius sp. 1 & 15 & 10 & 21 & 14 & 7 & 11 & 14 & 47 & 27 & 46 & 22 & 7 & 241 \\
\hline $2-$ & Ataen & 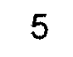 & 9 & 50 & 9 & 3 & 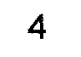 & 19 & 47 & 30 & 67 & 16 & 50 & 309 \\
\hline $3-$ & Onthophagus bucculus & 10 & 10 & 9 & 10 & 8 & 9 & 7 & 5 & 1 & 5 & 0 & 16 & 90 \\
\hline 4- & Onthophagus ranunculus & 0 & 3 & 1 & 0 & 0 & 0 & 0 & 0 & 0 & 1 & 1 & 2 & 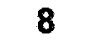 \\
\hline 5 & Ontho & 0 & 3 & 3 & 0 & 0 & 0 & 0 & 0 & 0 & 0 & 0 & 0 & 6 \\
\hline $6-$ & Ontho, & 0 & 1 & 25 & 4 & 12 & 2 & 6 & 3 & 3 & c & 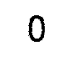 & 5 & 61 \\
\hline 7- & Onth & 0 & 0 & 0 & 0 & 2 & . & & 0 & 0 & 0 & 0 & 2 & 7 \\
\hline 8- & Digitor & 22 & 72 & 14 & 1 & 1 & 39 & 32 & 10 & 5 & 4 & 6 & 3 & 209 \\
\hline 9- & Ataen & 4 & 2 & 11 & 1 & 1 & 10 & 8 & 17 & 15 & 27 & 21 & 6 & 123 \\
\hline $10-$ & Cantl & 0 & 0 & 0 & 0 & 0 & 0 & 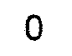 & 0 & 0 & 1 & 0 & 0 & 1 \\
\hline $11-$ & $c$ & 2 & 1 & 10 & 6 & 14 & 7 & 21 & 28 & 10 & 13 & 34 & 58 & 204 \\
\hline $12-$ & Cant & 6 & 0 & 1 & 0 & 0 & 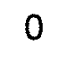 & 0 & 2 & 6 & 3 & 1 & 0 & 19 \\
\hline $13-$ & Canthon & 17 & 6 & 1 & 0 & 0 & 0 & 2 & 12 & 12 & $r$ & 4 & 8 & 69 \\
\hline 14- & Canthe & 4 & 2 & 0 & 0 & 0 & 0 & 0 & 6 & 6 & 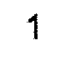 & 0 & 0 & 19 \\
\hline 15- & Cantr & 2 & 2 & 0 & 0 & 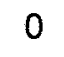 & 1 & 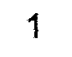 & 1 & 4 & & - & 4 & 19 \\
\hline 16- & Cantr & 2 & 3 & 5 & ${ }^{\prime}$ & 0 & 0 & 14 & 5 & 1 & . & 1 & 0 & 33 \\
\hline $17-$ & Cant & 0 & 1 & 0 & 0 & 0 & 4 & 11 & 2 & 1 & 5 & 2 & 11 & 37 \\
\hline $18-$ & $T$ & 5 & 2 & 2 & 1 & 0 & 0 & 24 & 62 & 10 & 16 & 3 & 10 & 135 \\
\hline 19- & Eury & 0 & 0 & 0 & 0 & . & 0 & & 1 & 0 & & 0 & & 3 \\
\hline $20-$ & Del & 0 & 0 & 0 & 0 & 0 & 0 & 0 & 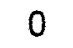 & 1 & 1 & 0 & 3 & 5 \\
\hline $21-$ & Cop & 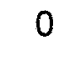 & 0 & 0 & 0 & 0 & 1 & 1 & 2 & 5 & 1 & 0 & 0 & 10 \\
\hline $22-$ & Gro & 0 & 1 & 1 & 0 & 0 & 0 & 3 & 0 & 0 & 0 & 0 & 0 & 5 \\
\hline 23- & Aphoc & 0 & 0 & 0 & 0 & 0 & 0 & 0 & 0 & 0 & 0 & 0 & 1 & 1 \\
\hline 24- & Aphoo & 0 & 0 & 2 & 6 & 18 & 3 & 0 & 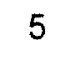 & 8 & 9 & 11 & 3 & 65 \\
\hline 25- & Onth & 17 & 45 & 20 & 4 & 14 & 88 & 75 & 49 & 7 & 62 & 13 & 29 & 423 \\
\hline 26- & Onthe & 0 & 0 & 0 & 0 & 0 & 0 & 0 & 3 & 0 & 0 & 0 & 0 & \\
\hline $27-$ & Onth & 0 & 0 & 0 & 0 & 0 & 0 & 0 & 0 & 1 & 0 & 0 & 0 & 1 \\
\hline 28- & Onthe & 0 & 0 & 0 & 0 & 0 & 0 & 1 & 0 & 0 & c & 0 & 1 & 2 \\
\hline $29-$ & Dicho & 0 & 0 & 0 & 0 & 0 & 0 & 0 & 1 & 0 & 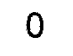 & 0 & 0 & 1 \\
\hline 30- & Dichot & 8 & 5 & 0 & 0 & 0 & 0 & 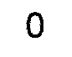 & 0 & 0 & 19 & 5 & 9 & 46 \\
\hline 31- & & v & 0 & 0 & 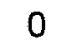 & 0 & 0 & $u$ & 0 & 0 & 0 & 0 & 1 & 1 \\
\hline $32-$ & Dic & 8 & 0 & 0 & 0 & 0 & 2 & 11 & 33 & 14 & 1 & 5 & 1 & 75 \\
\hline 33- & Dichotomius carbonarius & 0 & 0 & 0 & 0 & 0 & 0 & 1 & 2 & 1 & 2 & 1 & 0 & 7 \\
\hline & Total de exemplares & 127 & 178 & 176 & 57 & 81 & 181 & 254 & 343 & 168 & 295 & 148 & 229 & 2238 \\
\hline & Número de espécies & 15 & 18 & 16 & 11 & 11 & 13 & 19 & 22 & 21 & 23 & 16 & 21 & \\
\hline
\end{tabular}


$\mathrm{Na}$ Figura 2 ilustra-se a classificação dos besouros coprófagos coletados na área de pastagem de acordo com seu comportamento de nidificação.

\section{$\square$ Endocoprídeo $\square$ Telecoprídeo $\square$ Paracoprídeo}

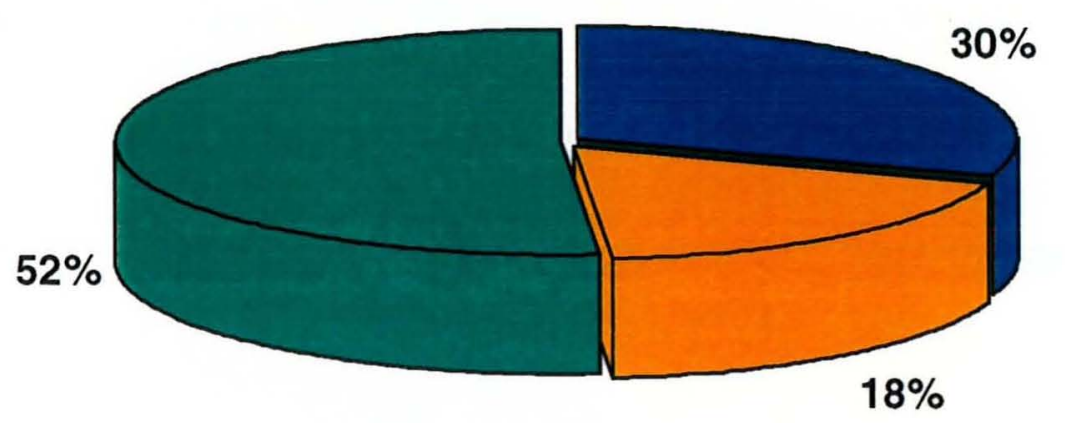

Figura 2 Coprófagos coletados na área de pastagem, segundo seu comportamento de nidificação-alimentação, com armadilhas "pitfall" iscadas com fezes de bovinos, no período de 04-03-98 a 28-02-99, em Pedro Juan Caballero-Paraguai.

Menor número de indivíduos e espécies foram recolhidos nos meses de junho e julho, coincidente com a época de temperaturas mais baixas e de menores precipitações. Nesses meses foram coletados 57 e 81 indivíduos equivalentes a 2,5 e 3,6\% da população respectivamente, com 11 espécies para cada mês.

Os picos populacionais foram verificados nos meses de outubro e dezembro, com 343 (15\%) e 295 indivíduos (13.2\%) da população, respectivamente. Entretanto, um representativo número de exemplares foi 
também capturado nos meses de setembro e fevereiro, com 254 e 229 indivíduos, respectivamente (Figura 3).

No mês de dezembro foram capturadas 23 espécies, constituindo-se assim na maior variação observada, representando $11,2 \%$ do total das espécies nos diferentes meses. Nos meses de outubro, novembro e fevereiro foram capturadas 22, 21 e 21 espécies, respectivamente (Figura 3).

- Número de indivíduos $\rightarrow$ Número de espécies

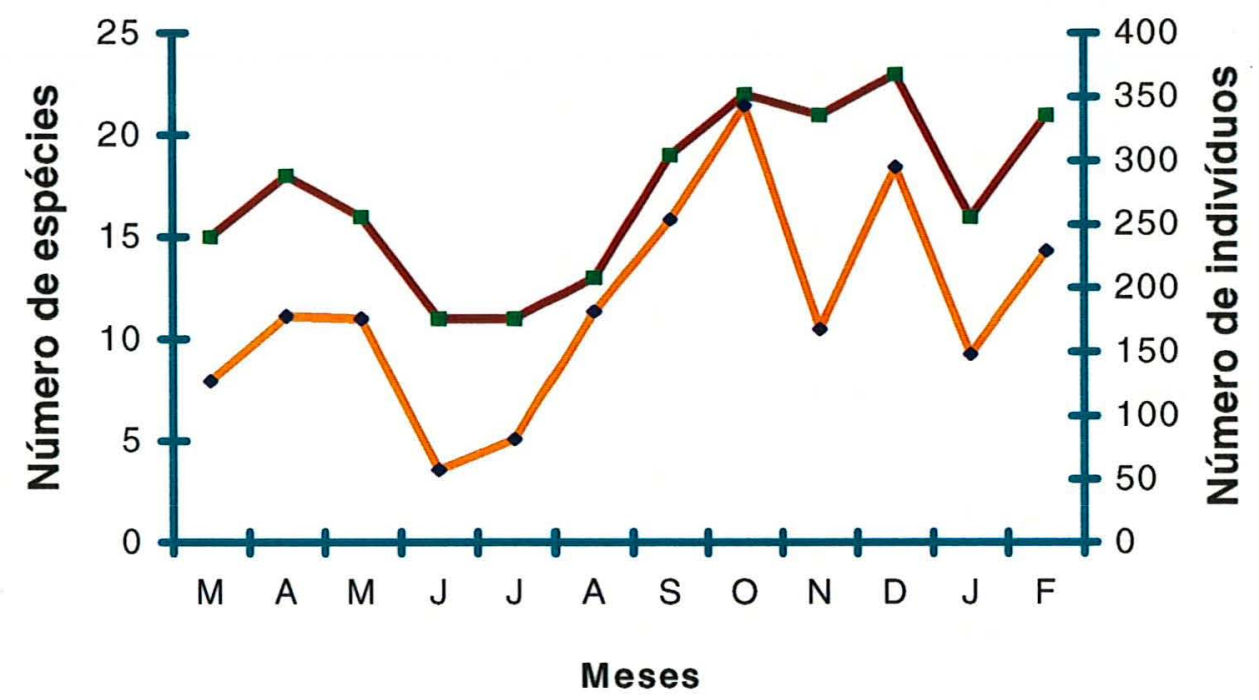

Figura 3 Número de espécies e indivíduos capturados com armadilhas "pitfall" iscadas com fezes de bovinos, na área de pastagem, no período de 04-03-98 a 28-02-99, em Pedro Juan Caballero-Paraguai.

Os paracoprídeos com 17 espécies, representando $52 \%$ dos insetos coletados, sendo os mais numerosos dentro dos 3 grupos de besouros coprófagos, teve as seguintes espécies como as principais: O. sulcator, 423 indivíduos (18,9\%) e Digitonthophagus gazella com 209 exemplares (9,3\% da população). As espécies capturadas em menor número dentro deste grupo 
foram: D. ascanius, Ontherus sp. $1 \mathrm{com}$ um individuo, Ontherus azteca com 2 e O. appendiculatus com 3 exemplares.

Besouros do grupo dos telecoprídeos não foram coletados nos meses do ano de temperaturas mais baixas e secas (maio, junho e julho), sendo observados em maior número nos meses de setembro, outubro e novembro. $\mathrm{O}$ gênero Canthon representado principalmente pelas seguintes espécies: C. quinquemaculatus, $(3,1 \%), C$. paraguayanum $(0,8 \%)$, C. septemmaculatus $(1,6 \%)$ e C. lituratus $1,47 \%$ da população, além de Deltochillum sp. $(0,22 \%)$ não foram capturados nos meses mencionados. A ocorrência de diapausa, neste grupo, foi relatado na África por Edwards (1988) o que poderia explicar o desaparecimento destas espécies no inverno.

O comportamento geral dos coprófagos nesta área foi similar aos encontrados na literatura, onde são mencionados como fatores determinantes da composição de espécies e flutuação populacional a temperatura, precipitação pluvial, condições do solo, etc. (Ridsdill-Smith, 1986), e ainda a textura do solo (Fincher \& Hunter, 1989).

\subsubsection{Espécies na área de mata}

$\mathrm{Na}$ mata foram coletados 3.754 exemplares em 32 espécies, verificando-se maior número de indivíduos e de espécies entre os meses de setembro a fevereiro (Tabela 3 ).

Das espécies Canthidium barbacenicum, Aphodius lividus, Ontherus appendiculatus, Dichotomius sp.2, Dichotomius mormom e Coprophaneus horus foram capturadas somente 1 exemplar de cada uma, representando apenas $0,03 \%$ da população. 
Tabela 3 Total de indivíduos e número de espécies coletadas mensalmente com armadilhas "pitfall" iscadas com fezes de bovinos, na área de mata, no período de 04-03-98 a 28-02-99, em Pedro Juan CaballeroParaguai.

\begin{tabular}{|c|c|c|c|c|c|c|c|c|c|c|c|c|c|}
\hline Meses & $\mathbf{M}$ & A & $\mathbf{M}$ & $\mathrm{J}$ & $\mathrm{J}$ & A & $\mathbf{s}$ & 0 & $\mathbf{N}$ & D & $\mathrm{J}$ & $\mathbf{F}$ & Total \\
\hline 1- Ataenius sp. 1 & 0 & 1 & 2 & 1 & 4 & 0 & 4 & 3 & 0 & 0 & 0 & 0 & 15 \\
\hline 2- Ataenius sculptor & 0 & 0 & 0 & 0 & 6 & 0 & 3 & 0 & 0 & 1 & 0 & 0 & 10 \\
\hline 3- Ataenius sp. 2 & 0 & 0 & 0 & 0 & 15 & 0 & 0 & 1 & 0 & 0 & 0 & 0 & 16 \\
\hline 4- Aphodius lividus & 0 & 0 & 0 & 0 & 0 & 0 & 1 & 0 & 0 & 0 & 0 & 0 & 1 \\
\hline 5- Cartwrightia cartwrighti & 0 & 0 & 0 & 0 & 0 & 0 & 7 & 0 & 1 & 0 & 0 & 0 & 8 \\
\hline 6- Onthophagus bucculus & 23 & 6 & 6 & 9 & 4 & 10 & 19 & 15 & 18 & 28 & 10 & 55 & 203 \\
\hline 7- Onthophagus sp. 1 & 31 & 14 & 26 & 43 & 70 & 59 & 26 & 47 & 40 & 105 & 25 & 38 & 524 \\
\hline 8- Onthophagus hirculus & 11 & 7 & 13 & 15 & 22 & 14 & 24 & 24 & 32 & 26 & 16 & 23 & 227 \\
\hline 9- Onthophagus sp.2 & 0 & 1 & 1 & 13 & 24 & 35 & 9 & 2 & 12 & 21 & 6 & 5 & 129 \\
\hline 10- Onthophagus sp. 3 & 0 & 0 & 0 & 2 & 0 & 1 & 0 & 0 & 2 & 0 & 2 & 1 & 8 \\
\hline 11- Canthon curvodilataus & 0 & 0 & 0 & 0 & 0 & 0 & 3 & 3 & 3 & 4 & 0 & 4 & 17 \\
\hline 12- Canthon paraguayanum & 1 & 0 & 0 & 0 & 1 & 1 & 2 & 8 & 1 & 0 & 10 & 8 & 32 \\
\hline 13- Canthon quinquemaculatus & 4 & 2 & 0 & 0 & 0 & 3 & 8 & 22 & 27 & 13 & 10 & 20 & 109 \\
\hline 14- Canthon lituratus & 0 & 0 & 0 & 0 & 0 & 0 & 3 & 0 & 0 & 0 & 0 & 0 & 3 \\
\hline 15- Canthon septemmaculatus & 4 & 1 & 1 & 0 & 2 & 5 & 8 & 13 & 2 & 12 & 14 & 17 & 79 \\
\hline 16- Canthon luctuosum & 7 & 0 & 0 & 0 & 0 & 0 & 0 & 0 & 3 & 0 & 11 & 22 & 43 \\
\hline 17- Canthidium barbacenicum & 0 & 0 & 0 & 0 & 0 & 0 & 0 & 0 & 1 & 0 & 0 & 0 & 1 \\
\hline 18- Canthidium breve & 0 & 0 & 0 & 0 & 1 & 0 & 1 & 3 & 0 & 2 & 11 & 10 & 28 \\
\hline 19- Canthidium megathopoides & 0 & 0 & 0 & 0 & 0 & 0 & 0 & 0 & 0 & 0 & 0 & 2 & 2 \\
\hline 20 Eurysternus caribaeus & 4 & 0 & 0 & 0 & 7 & 29 & 24 & 27 & 43 & 36 & 11 & 31 & 212 \\
\hline 21- Eurysternus paralellus & 135 & 3 & 15 & 5 & 25 & 75 & 1181 & 128 & 121 & 352 & 256 & 304 & 1537 \\
\hline 22- Eurystemus plebejus & 9 & 0 & 0 & 0 & 8 & 5 & 9 & 2 & 2 & 3 & 6 & 12 & 56 \\
\hline 23- Ontherus azteca & 1 & 0 & 0 & 0 & 1 & 0 & 0 & 0 & 0 & 7 & 0 & 0 & 9 \\
\hline 24- Ontherus sulcator & 5 & 1 & 0 & 3 & 6 & 44 & 29 & 4 & 1 & 8 & 8 & 8 & 117 \\
\hline 25- Ontherus appendiculatus & 0 & 0 & 0 & 0 & 0 & 0 & 0 & 0 & 0 & 1 & 0 & 0 & 1 \\
\hline 26- Dichotomius nisus & 3 & 0 & 0 & 0 & 16 & 2 & 3 & 1 & 1 & 2 & 1 & 1 & 30 \\
\hline 27- Dichotomius carbonarius & 7 & 0 & 0 & 0 & 0 & 0 & 11 & 109 & 75 & 61 & 5 & 12 & 270 \\
\hline 28- Dichotomius sp.2 & 0 & 0 & 0 & 0 & 0 & 0 & 0 & 0 & 1 & 0 & 0 & 0 & 1 \\
\hline 29- Dichotomius mormom & 0 & 0 & 0 & 0 & 0 & 0 & 0 & 0 & 0 & 1 & 0 & 0 & 1 \\
\hline 30- Deltochillum sp. & 3 & 0 & 0 & 0 & 0 & 4 & 8 & 11 & 4 & 6 & 9 & 5 & 50 \\
\hline 31- Coprophaneus jasius & 2 & 0 & 0 & 0 & 0 & 0 & 2 & 4 & 1 & 2 & 1 & 2 & 14 \\
\hline 32- Coprophaneus horus & 0 & 0 & 0 & 0 & 0 & 0 & 0 & 0 & 0 & 0 & 0 & 1 & 1 \\
\hline Total de exemplares & 250 & 36 & 64 & 91 & 212 & 287 & 3124 & 427 & 391 & 691 & 412 & 581 & 3754 \\
\hline Número de espécies & 16 & 9 & 7 & 8 & 16 & 14 & 22 & 19 & 21 & 19 & 18 & 21 & \\
\hline
\end{tabular}


O endocoprídeo Eurysternus paralellus, com 1537 indivíduos, representando $40,9 \%$ da população total, foi a espécie predominante, seguida pelo Onthophagus sp.1, com 524 indivíduos equivalente a 13,9\% da população coletada.

O grupo dos paracoprídeos foi o mais numeroso com 14 espécies, representando $44 \%$ do grupo, seguido numericamente dos endocoprídeos com $34 \%$ (11 espécies) e em menor número os telecoprídeos com 22\% (12 espécies) (Figura 4).

\section{$\square$ Endocoprídeo $\square$ Paracoprídeo $\square$ Telecoprídeo}

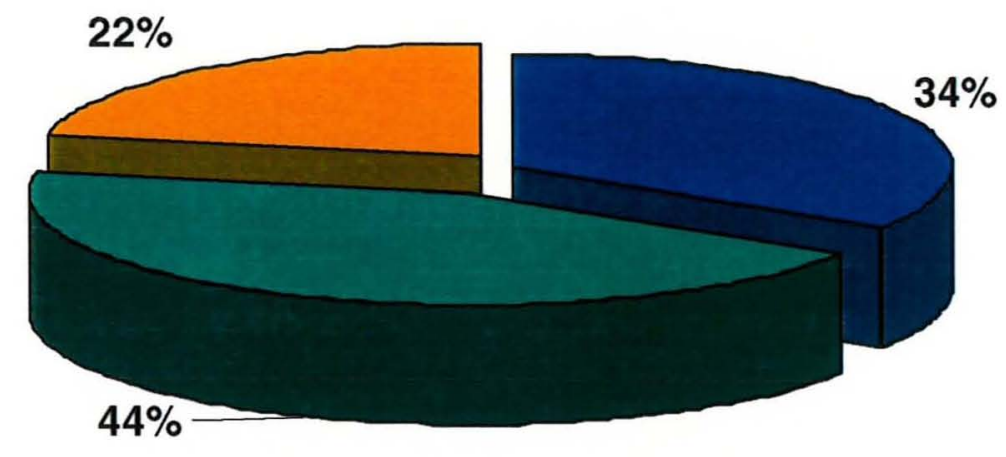

Figura 4 Grupos de Coprófagos coletados com armadilhas "pitfall" iscadas com fezes de bovinos, segundo seu comportamento de nidificaçãoalimentação, na área de mata, no período de 04-03-98 a 28-02-99, em Pedro Juan Caballero-Paraguai.

Os picos populacionais do endocoprídeo $E$. paralellus e do paracoprídeo Onthophagus sp.1 com 352 e 105 exemplares, respectivamente, ocorreram no mês de dezembro e do 0 . bucculus com 55 indivíduos, no mês de fevereiro embora tenham sido coletados durante todo o período de amostragem. 
O paracoprídeo $O$. hirculus com 32 indivíduos coletados apresentou comportamento semelhante às espécies anteriores com pico populacional no mês de novembro.

Quanto ao número total de individuos capturados, o pico populacional ocorreu no mês de dezembro, com 691 exemplares, representando $18,4 \%$ da população total capturada nos diferentes meses. No mês de fevereiro, coletouse 581 exemplares, que equivalem a $15,5 \%$ da população.

Nos meses de abril, maio e junho, foram capturados os menores números de indivíduos com 36, 64 e 91 exemplares, representando apenas $0,95 \%, 1,7 \%$ e $2,4 \%$ da população, respectivamente.

Coincidentemente com o número reduzido de indivíduos coletados nos meses de maio e junho foram também capturados os menores números de espécies (7 e 8), respectivamente (Figura 5).

Com respeito ao número de espécies, os valores mais elevados foram observados entre os meses de setembro e fevereiro, ocorrendo um pico de variação no mês de setembro, com a coleta de 22 espécies diferentes.

As espécies de Onthophagus e Canthidium representam aproximadamente $30 \%$ da população o que segundo Rivera-Cervantes \& Garcia-Real (1998), a predominância desses tipos de insetos poderia sugerir que sejam espécies indicadoras de perturbações ocasionadas por fogo, considerando que a área estudada passou por queimada no ano 1997. 


\section{—Número de espécies $\longrightarrow$ Número de indivíduos}

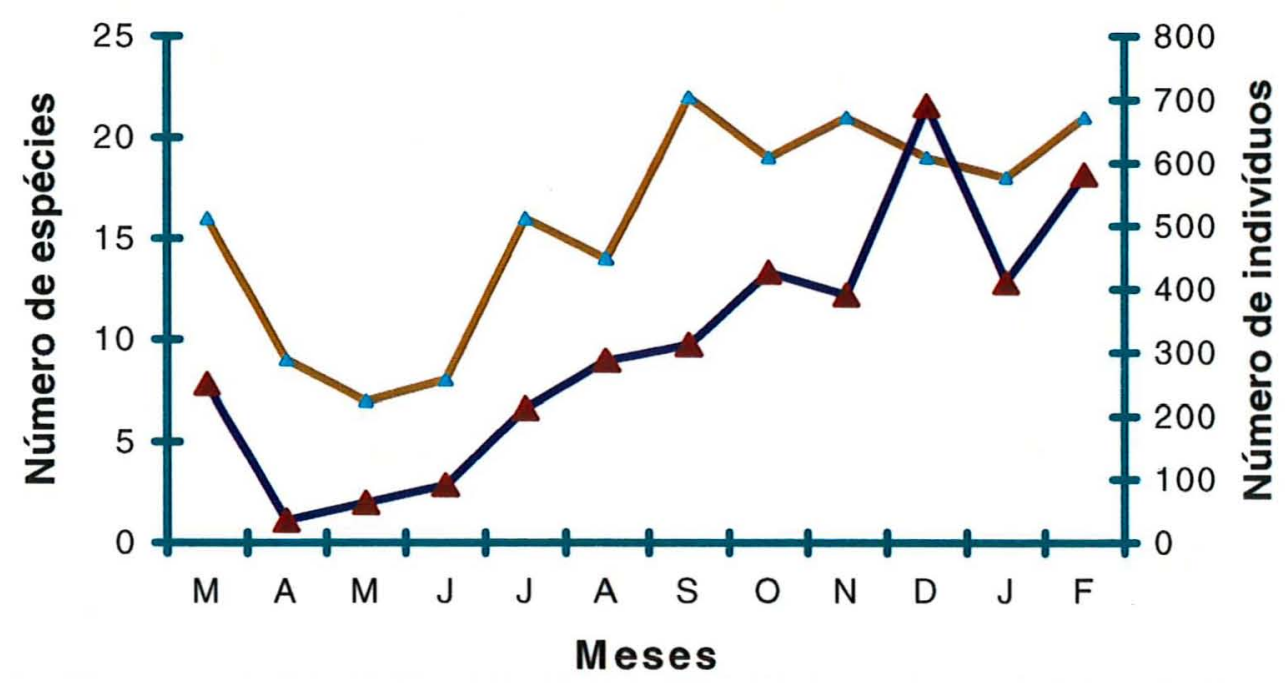

Figura 5 Número de espécies e indivíduos capturados com armadilhas "pitfall" iscadas com fezes de bovinos, na área de mata, no período de 04-0398 a 28-02-99, em Pedro Juan Caballero-Paraguai.

O comportamento dos besouros coprófagos nesta área evidenciou a influência de fatores externos na composição das espécies. O fato de ter sido encontrado neste trabalho maior quantidade de espécie na pastagem (33), do que na mata (32), pode ser explicado, primeiro: pelo tipo de isca utilizado, considerando que as fezes de gado bovino usado como atraente neste experimento são mais eficientes na pastagem do que na mata, como foi comprovado por Assis Júnior et al. (1999); segundo: pela fragmentação da floresta estudada, o que segundo Kleim (1989), provoca mudanças de microclima (umidade e temperatura) promovendo importantes alterações no desenvolvimento e sobrevivência na comunidade dos coprófagos; terceiro: a área estudada tem aproximadamente $100 \mathrm{ha}$, sendo apenas um fragmento da cobertura florestal original que cobria aproximadamente $80 \%$ da superfície do estado. É conhecido que espécies que requerem grandes extensões florestais não conseguem sobreviver em pequenos fragmentos (Bierregaard Jr et al., 
1992, Kruess \& Tscharntke, 1994, Laurence et al., 1997) o que provavelmente também contribuiu para este fato.

\subsubsection{Espécies na área semi-urbana}

As espécies capturadas na área semi-urbana são citadas na Tabela 4

Tabela 4 Total de indivíduos e número de espécies coletadas mensalmente com armadilhas "pitfall" iscadas com fezes de bovinos, na área semi-urbana, no período de 04-03-98 a 20-02-99, em Pedro Juan Caballero-Paraguai.

\begin{tabular}{|c|c|c|c|c|c|c|c|c|c|c|c|c|c|}
\hline Espécies & $\mathbf{M}$ & A & $\mathbf{M}$ & $J$ & J & A & $\mathbf{S}$ & 0 & $\mathbf{N}$ & D & $J$ & $\mathbf{F}$ & Tota \\
\hline 1- Ataenius sp. 1 & 50 & 21 & 11 & 9 & 27 & 12 & 98 & 50 & 66 & 130 & 26 & 25 & 525 \\
\hline 2- Ataenius sculptor & 8 & 10 & 17 & 7 & 3 & 0 & 6 & 12 & 18 & 33 & 28 & 12 & 154 \\
\hline 3- Ataenius sp.2 & 1 & 0 & 0 & 2 & 0 & 1 & 21 & 5 & 15 & 18 & 28 & 8 & 99 \\
\hline 4- Ataenius sp. 3 & 0 & 0 & 0 & 0 & 0 & 0 & 0 & 0 & 1 & 0 & 0 & 0 & 1 \\
\hline 5- Aphodius lividus & 0 & 0 & 0 & 0 & -0 & 4 & 12 & 7 & 7 & 8 & 13 & 3 & 54 \\
\hline 6- Aphodius sp. & 0 & 0 & 0 & 0 & 0 & 0 & 0 & 4 & 3 & 2 & 2 & 1 & 12 \\
\hline 7- Onthophagus bucculus & 2 & 6 & 12 & 4 & 4 & 9 & 10 & 6 & 6 & 5 & 13 & 11 & 88 \\
\hline 8- Onthophagus sp.1 & 0 & 1 & 0 & 0 & 0 & 0 & 1 & 0 & 0 & 0 & 0 & 0 & 2 \\
\hline 9- Onthophagus ranunculus & 5 & 4 & 1 & 0 & 1 & 0 & 2 & 1 & 4 & 1 & 0 & 1 & 20 \\
\hline 10- Onthophagus hirculus & 0 & 8 & 5 & 3 & 0 & 0 & 7 & 10 & 3 & 6 & 0 & 6 & 48 \\
\hline 11- Onthophagus sp.2 & 0 & 0 & 0 & 0 & 0 & 0 & 1 & 0 & 3 & 0 & 0 & 0 & 4 \\
\hline 12- Digitonthophagus gazella & 13 & 5 & 1 & 0 & 0 & 6 & 23 & 0 & 0 & 0 & 6 & 5 & 59 \\
\hline 13- Dichotomius nisus & 0 & 0 & 0 & 0 & 0 & 0 & 0 & 2 & 0 & 0 & 0 & 0 & 2 \\
\hline 14- Dichotomius bos & 0 & 0 & 0 & 0 & 0 & 0 & 0 & 0 & 0 & 0 & 2 & 7 & 9 \\
\hline 15- Canthon curvodilataus & 0 & 0 & 0 & 0 & 0 & 1 & 0 & 0 & 0 & 0 & 0 & 0 & 1 \\
\hline 16- Canthon paraguayanum & 0 & 0 & 0 & 0 & 0 & 0 & 0 & 1 & 0 & 0 & 2 & 0 & 3 \\
\hline 17- Canthon septemmaculatus & 0 & 0 & 0 & 0 & 0 & 0 & 0 & 2 & 0 & 1 & 1 & 0 & 4 \\
\hline 18- Canthon sp. & 0 & 0 & 0 & 0 & 0 & 0 & 0 & 1 & 0 & 0 & 0 & 0 & 1 \\
\hline 19- Trichillum externepunctatum & 0 & 5 & 0 & 0 & 0 & 0 & 3 & 6 & 2 & 0 & 0 & 0 & 16 \\
\hline 20- Canthidium breve & 0 & 0 & 1 & 0 & 0 & 1 & 2 & 5 & 0 & 1 & 6 & 3 & 19 \\
\hline 21- Ontherus sulcator & 0 & 0 & 0 & 0 & 0 & 1 & 5 & 8 & 0 & 1 & 2 & 2 & 19 \\
\hline 22- Ontherus appendiculatus & 0 & 0 & 0 & 0 & 0 & 0 & 0 & 1 & 0 & 0 & 0 & 0 & 1 \\
\hline 23- Diabroctis mimas & 0 & 0 & 0 & 0 & 0 & 0 & 0 & 0 & 0 & 0 & 0 & 1 & 1 \\
\hline Número de individuos & 79 & 60 & 48 & 25 & 35 & 35 & 191 & 121 & 128 & 206 & 129 & 85 & 1142 \\
\hline Número de espécies & 6 & 8 & 7 & 5 & 4 & 8 & 12 & 16 & 11 & 11 & 12 & 13 & \\
\hline
\end{tabular}


De acordo com seu hábito de nidificação-alimentação foram encontradas 8 espécies de endocoprídeos 11 de paracoprídeos e 4 dos telecoprídeos, equivalente a 35\%, 48\% 17\% da população, respectivamente (Figura 6).

$\square$ Telecoprídeos $\square$ Endocoprídeos $\square$ Paracoprídeos

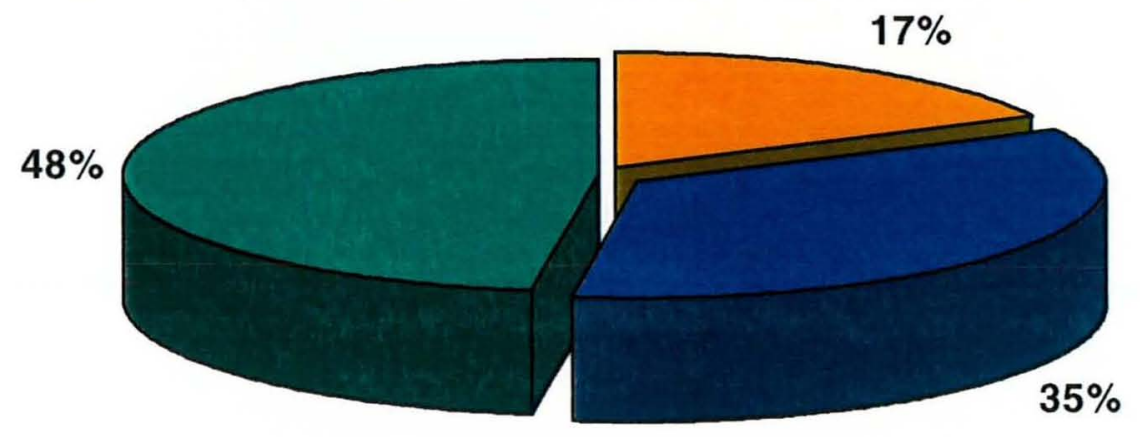

Figura 6 Percentagem de coprófagos coletados com armadilhas "pitfall" iscadas com fezes de bovinos, na área semi-urbana, segundo seu comportamento de nidificação-alimentação, no período de 04-03-98 a 28-02-99, em Pedro Juan Caballero-Paraguai.

A área semi-urbana foi a que apresentou o menor número de indivíduos e espécies capturadas. Foram verificados 1.142 indivíduos em 23 espécies dos quais Ataenius sp.1 foi a mais numerosa com 525 indivíduos representando $46 \%$ da população total. Em seguida, encontra-se A. sculptor com 154 indivíduos e 13,5\% da população total. Com apenas 1 indivíduo foram observadas as espécies C. curvodilataus, O. appendiculatus, Ataenius sp.3 e com 2 exemplares D. mimas, e Onthophagus sp.1. 
Em relação ao número de espécies e indivíduos capturados nos diferentes meses foi observado comportamento semelhante às áreas de mata $\mathrm{e}$ pastagem, já que foi capturado maior número de exemplares nos meses com temperaturas médias mais altas. Os picos populacionais foram observados nos meses de dezembro e setembro (Figura 7).

$\longrightarrow$ Número de indivíduos $\rightarrow$ Número de espécies

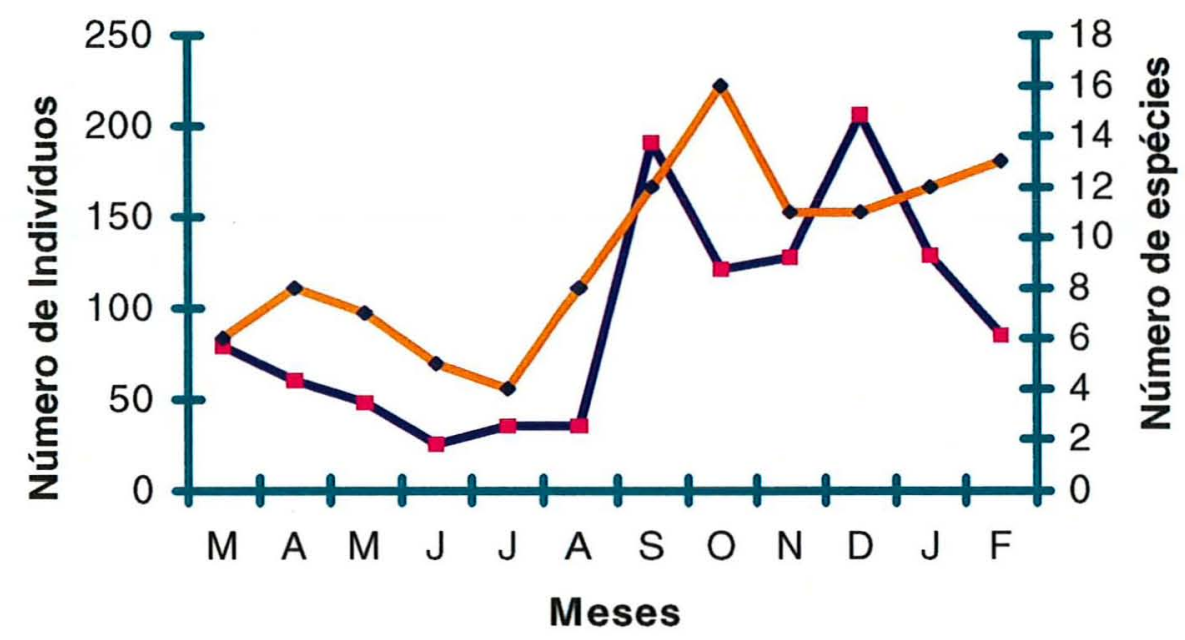

Figura 7 Número de espécies e indivíduos capturados com armadilhas "pitfall" iscadas com fezes de bovinos, na área de mata, no período de 04-03-98 a 28-02-99, em Pedro Juan CaballeroParaguai.

\subsection{Comportamento em relação aos fatores climáticos}

Os fatores climáticos podem ter favorecido a coleta de maior número de espécies e de indivíduos nos meses mais quentes e chuvosos do ano, que engloba os meses de setembro até fevereiro, em relação a os mais frios e secos como maio, junho e julho (Figuras 8). 


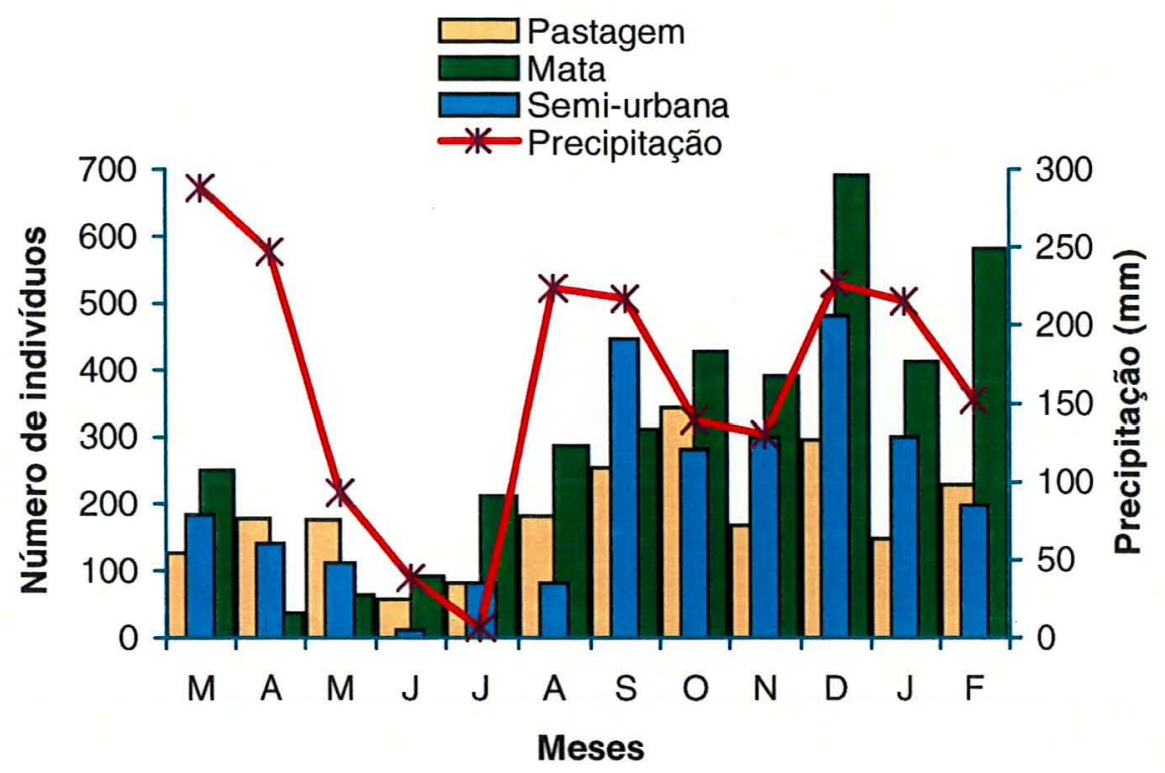

Figura 8 Número de indivíduos coletados com armadilhas "pitfall" nas diferentes áreas e precipitação mensal $(\mathrm{mm})$ de março/98 a fevereiro/99, obtidos da Estação Meteorológica do Aeroporto Internacional de Pedro Juan Caballero-Paraguai.

Com respeito ao maior número de indivíduos capturados na mata, acredita-se que seja devido às temperaturas mais uniformes que na área de pastagem, onde ocorrem maiores oscilações térmicas o que pode ter desfavorecido a permanência e coleta das espécies em discussão e também o fator vento, pois este é mais constante e intenso na pastagem e área semiurbana do que na área de mata, como foi comprovada por Halffter \& Edmonds (1992) e Rodrigues (1996).

A vegetação presente na área de mata principalmente, como presença de sub-bosque, que proporciona maior sombreamento na camada superficial de solo, provocam menores temperaturas e menores oscilações térmicas (Rodrigues, 1996). Esses fatores influem na formação de diferentes 
microclimas, e para os besouros coprófagos tornam-se muito importantes podendo explicar, em parte, porque algumas espécies ocorrem apenas num determinado ambiente.

$\square$ Pastagem $\square$ Semi-urbana —-Média Gral. —Mata

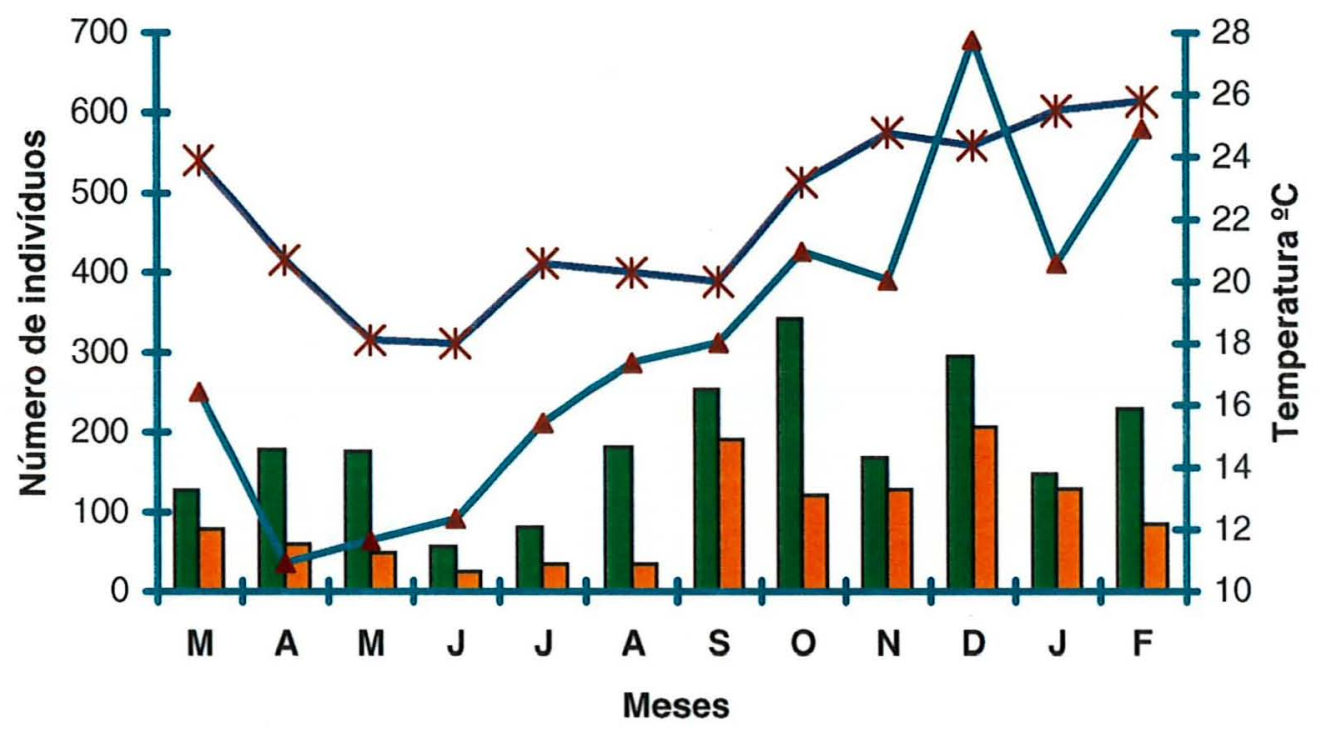

Figura 8 Número de indivíduos capturados nas 3 áreas de coleta com armadilhas "pitfall" e temperatura média geral em $\stackrel{\circ}{ } \mathrm{C}$ durante os meses de março/98 a fevereiro/99, obtidas da estação meteorológica do aeroporto internacional de Pedro Juan CaballeroParaguai.

Com respeito ao número de espécies capturadas o fator climático (temperatura e precipitação) pode ter também favorecido a coleta de maior variação nas diferentes áreas nos meses mais quentes e chuvosos do ano, compreendidas entre setembro até fevereiro (Tabela 5). 
Tabela 5 Número de espécies de coprófagos capturadas com armadilhas "pitfall" iscadas com fezes de bovinos, nas diferentes áreas em relação à precipitação e temperatura, durante os meses de março 98 a fevereiro 99, em Pedro Juan Caballero-Paraguai.

\begin{tabular}{cccccc}
\hline Meses & $\begin{array}{c}\text { Temperatura } \\
\text { média }\left({ }^{\circ} \mathrm{C}\right)\end{array}$ & $\begin{array}{c}\text { Númecipitação }(\mathrm{mm}) \\
\text { Preciagem }\end{array}$ & $\begin{array}{c}\text { Mata } \\
\text { Pastácies }\end{array}$ & Semi-urbana \\
\hline M & 23,9 & 288,4 & 15 & 16 & 6 \\
A & 20,7 & 247 & 18 & 9 & 8 \\
M & 18,1 & 92,7 & 16 & 7 & 7 \\
J & 18 & 38,3 & 11 & 8 & 5 \\
J & 20,6 & 6,3 & 11 & 16 & 4 \\
A & 20,3 & 223,9 & 13 & 14 & 8 \\
S & 20 & 216,8 & 19 & 22 & 12 \\
O & 23,2 & 139 & 22 & 19 & 16 \\
N & 24,8 & 129,8 & 21 & 21 & 11 \\
D & 24,4 & 226,7 & 23 & 19 & 11 \\
J & 25,5 & 215 & 16 & 18 & 12 \\
F & 25,8 & 152,1 & 21 & 21 & 13 \\
\hline
\end{tabular}

Correlacionando a precipitação com a quantidade de espécies e indivíduos capturados no periodo de coleta através do calculo da regressão polinomial, comprovou-se que a precipitação até os $150 \mathrm{~mm}$ favorece a coleta de maior número de espécies e individuos e que acima desse valor os 2 componentes diminuem; esse fato é bem marcante nas áreas de pastagem e semi-urbana, no entanto, na mata observou-se menor resposta às precipitações, provavelmente por ser uma área de maior equilibrio. A confiabilidade no resultado variou entre 39 a $84 \%$ (Figura 9 a, b).

Correlacionando a temperatura média com a quantidade de espécies e indivíduos capturados, através do cálculo da regressão polinomial, foi evidenciado que na maior temperatura captura-se maior número de indivíduos e espécies, nas diferentes áreas de coleta, variando a confiabilidade entre 45 a $76 \%$ (Figura $10 \mathrm{a}, \mathrm{b}$ ). 


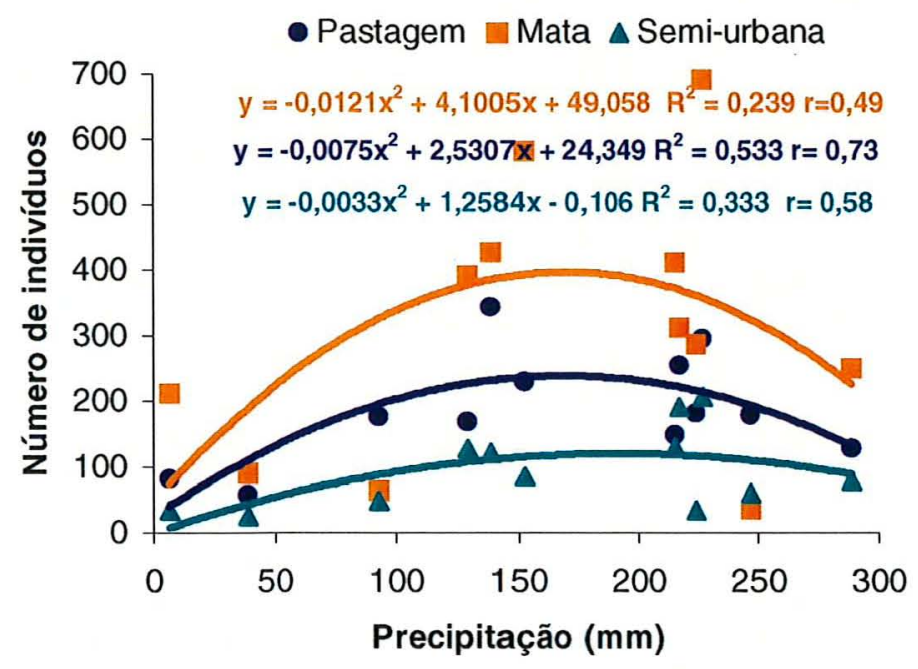

(a)



(b)

Figura $9(a, b)$ Correlação polinomial da precipitação com número de espécies e indivíduos capturados com armadilhas "pitfall" iscadas com fezes de bovinos, nas 3 áreas de coleta, no período de 04-0398 a 28-02-99, em Pedro Juan Caballero-Paraguai. 


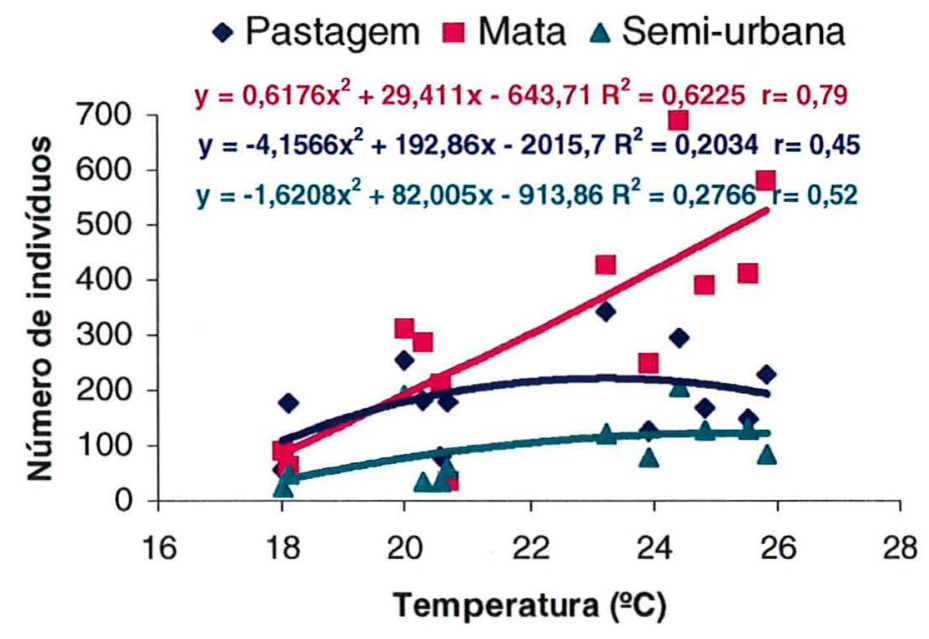

(a)

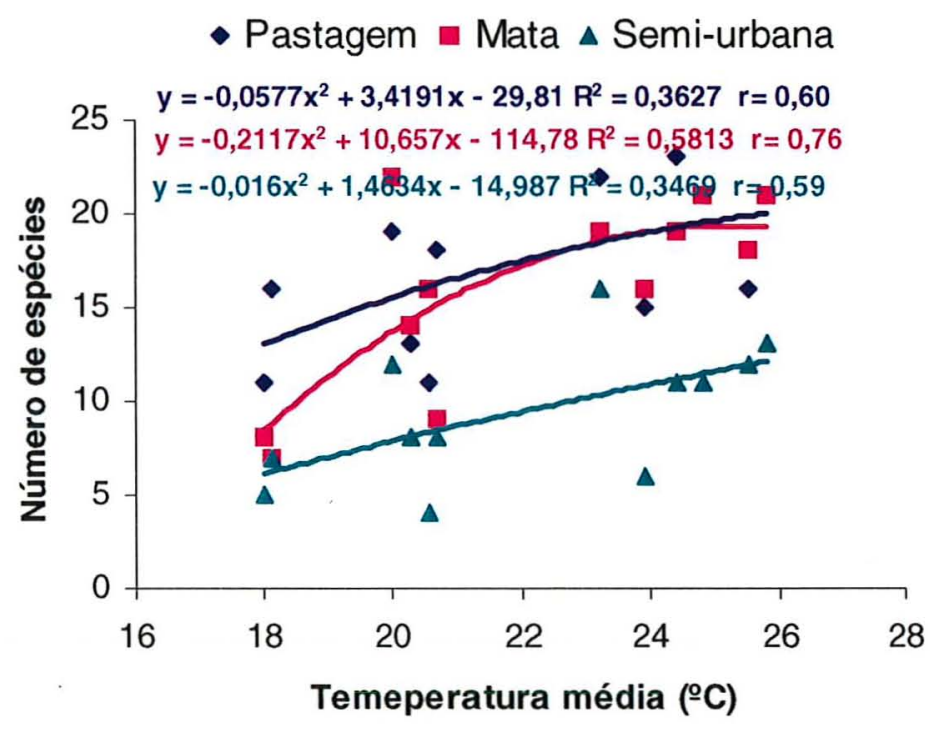

(b)

Figura $10(a, b)$ Correlação polinomial da temperatura com número de espécies e indivíduos capturados com armadilhas "pitfall" iscadas com fezes de bovinos, nas 3 áreas de coleta, no período de 04-0398 a 28-02-99, em Pedro Juan Caballero-Paraguai. 


\subsection{Caracterização das comunidades}

4.3.1 Índices de freqüência, abundância, constância, dominância e diversidade.

\subsubsection{1 Área de Pastagem}

A distribuição percentual da análise faunística das espécies capturadas na área de pastagem esta apresentada na Tabela 8.

Tabela 8 Distribuição percentual das espécies de besouros coprófagos capturados com armadilhas "pitfall" iscadas com fezes de bovinos, em área de pastagem, no periodo de 04-03-98 a 28-02-99, em Pedro Juan Caballero-Paraguai.

\begin{tabular}{|c|c|c|c|}
\hline Indices faunísticos & Classificação & Total & $\%$ \\
\hline & Muito Freqüente (MF) & 7 & 21,2 \\
\hline \multirow[t]{4}{*}{ FREQÜENCIA } & Freqüente & 7 & 21,2 \\
\hline & Pouco Freqüente (PF) & 19 & 57,6 \\
\hline & Muito Abundante (ma) & 7 & 21,2 \\
\hline & Abundante & 0 & 0 \\
\hline \multirow[t]{4}{*}{ ABUNDÂNCIA } & Comum & 7 & 21,2 \\
\hline & Dispersa & 1 & 3 \\
\hline & Rara & 18 & 54,6 \\
\hline & Constante & 10 & 30,3 \\
\hline \multirow[t]{2}{*}{ CONSTÂNCIA } & Acessória & 7 & 21,2 \\
\hline & Acidental & 16 & 48,5 \\
\hline \multirow[t]{2}{*}{ DOMINÂNCIA } & Dominante & 23 & 69,7 \\
\hline & Não Dominante (ND) & 10 & 30,3 \\
\hline \multicolumn{2}{|c|}{$\begin{array}{l}\text { Total de espécies...................... } 33 \\
\text { Total de individuos................. } 238 \\
\text { Indice de Diversidade (Shannon-Wiener).... } H^{\prime}=2.6442 \\
\text { Indice de Diversidade (Margalef)............... Alfa }=4.1847\end{array}$} & \multicolumn{2}{|c|}{$\begin{array}{l}\text { Indice de Equitabilidade....E }=0,7562 \\
\text { Variância ......................... }\end{array}$} \\
\hline
\end{tabular}


Analisando-se o indice de freqüência, observou-se que $57,6 \%$ das espécies coletadas se enquadram dentro da categoria pouco freqüente, e $21,2 \%$ em muito freqüente e freqüente, respectivamente.

O indice de constância mostrou que $30,3 \%$ da população são constantes, $21,2 \%$ acessórias e $48,5 \%$ se encontram na categoria acidental. As mesmas espécies classificadas como muito freqüente, alem de $O$. bucculus, $C$. quinquemaculatus e A. lividus, encontram-se na categoria constante.

Os endocoprideos do gênero Ataenius sculptor, sp.1 e sp.2; Canthidium breve e Trichillum externepunctatum e os paracoprideos $D$. gazella, 0 . sulcator, foram classificados como muito freqüente, e os demais nas outras categorias.

Para o índice de abundância, $21,2 \%$ da população foi classificada como muito abundante não se encontrando espécies na categoria abundante; $54,6 \%$ foi classificada na categoria rara. As mesmas espécies que receberam a classificação de muito freqüente encontraram-se na categoria muito abundante.

As espécies dos gêneros Dichotomius: $D$. nisus e $D$. bos, e de Canthon: C. curvodilataum, C. paraguayanum, C. lituratus, C.septemmaculatus, encontraram-se na categoria acessória; A. lividus, e Canthidium breve encontram-se na categoria constantes. As demais espécies são classificadas na categoria acidental.

O Índice de dominância mostrou que as espécies dominantes foram de $69,7 \%$ e as não dominantes $30,3 \%$ da população

\subsubsection{2 Área semi-urbana}

A distribuição percentual da análise faunística das espécies capturadas na área semi-urbana esta apresentada na Tabela 9. 
$\mathrm{Na}$ área semi-urbana Ataenius sp.1 por ser uma espécie predominante em relação aos outros não foi considerado nas análises feitas para o cálculo dos diferentes indices, embora tenha recebido categorias exclusivas como a de super dominante, super abundante e super freqüente.

Tabela 9 Distribuição percentual das espécies de besouros coprófagos capturados em armadilhas "pitfall" iscadas com fezes de bovinos, em área semi-urbana, no período de 04-03-98 a 26-02-99, em Pedro Juan Caballero-Paraguai.

\begin{tabular}{|c|c|c|c|c|}
\hline \multirow[t]{2}{*}{ Índices faunisticos } & \multicolumn{2}{|c|}{ Classificação } & \multirow{2}{*}{$\begin{array}{c}\text { Total } \\
1\end{array}$} & \multirow{2}{*}{$\frac{\%}{4,4}$} \\
\hline & Super Freqüente & SF) & & \\
\hline \multirow[t]{4}{*}{ FREQÜÊNCIA } & Muito Freqüente & (MF) & 6 & 26,1 \\
\hline & Freqüente & $(F)$ & 5 & 21,7 \\
\hline & Pouco Freqüente & (PF) & 11 & 47,8 \\
\hline & Super Abundante & $(\mathrm{SA})$ & 1 & 4,3 \\
\hline \multirow{6}{*}{ ABUNDÂNCIA } & Muito Abundante & (ma) & 5 & 21,8 \\
\hline & Abundante & (a) & 1 & 4,3 \\
\hline & Comum & (c) & 5 & 21,8 \\
\hline & Dispersa & (d) & 1 & 4,3 \\
\hline & Rara & (r) & 10 & 43,5 \\
\hline & Constante & (W) & 5 & 21,7 \\
\hline \multirow[t]{3}{*}{ CONSTÂNCIA } & Acessória & $(\mathrm{Y})$ & 6 & 26,1 \\
\hline & Acidental & $(Z)$ & 12 & 52,2 \\
\hline & Super Dominante & (SD) & 1 & 4,4 \\
\hline \multirow[t]{2}{*}{ DOMINÂNCIA } & Dominante & (D) & 12 & 52,3 \\
\hline & Não Dominante & (ND) & 10 & 43,4 \\
\hline \multicolumn{3}{|c|}{$\begin{array}{l}\text { Total de espécies............... } 23 \\
\text { Total de indivíduos ........ } 1.140 \\
\text { Indice de Diversidade (Shannon - Wiener).... } H^{\prime}=1.9288 \\
\text { Indice de Diversidade (Margalef) ............... Alfa }=3.1248\end{array}$} & $\begin{array}{l}\text { e Eqüit } \\
\text { ia }\end{array}$ & $\begin{array}{l}=0.6151 \\
=0.0014\end{array}$ \\
\hline
\end{tabular}

* Método de Laroca e Mielke (1975)

$\mathrm{Na}$ categoria de abundância foram encontradas 10 espécies raras equivalendo a $43,5 \%$ da população. Nas categorias comum e muito abundante foram capturadas 5 espécies para cada um, correspondendo a $21,8 \%$ da 
população. Também foram encontradas maiores percentagens de espécies acidentais $(52,2 \%)$, diante das espécies acessórias $(26,1 \%)$ e constantes $(21,7 \%)$.

As espécies classificadas como pouco freqüentes foram encontradas também em maiores números com 11 espécies (47,8\%). 6 e 5 espécies foram classificadas como muito freqüente e freqüentes que corresponderam a $26,1 \mathrm{e}$ $21,7 \%$ da população total capturada, respectivamente.

Com respeito ao Índice de dominância, pelo método de Laroca e Mielke (1975) foi obtido 12 e $10 \%$ de espécies dominantes e não dominantes, respectivamente.

As espécies $A$. sculptor, $O$. bucculus, Ataenius sp. 2 foram classificadas como constante, muito freqüente, muito abundante, e dominante; $A$. lividus foi classificada como espécie acessória, muito abundante, muito freqüente e dominante.

\subsubsection{3 Área de mata}

A distribuição percentual da análise faunística das espécies capturadas na área de mata esta apresentada na Tabela 10.

A espécie $E$. paralellus recebeu uma categoria especial com respeito às demais porque o número de individuos coletados (1.537) excedeu muito e foi considerada somente para o cálculo do Índice da constância. Esta espécie foi classificada nas categorias de super dominante, super abundante e super freqüente. $O$ índice de constância indica que $34,4 \%$ da população, incluindo $E$. paralellus são constantes, $53,1 \%$ acidental e $12,5 \%$ acessória.

Com respeito à abundância $50 \%$ da população foram classificadas na categoria raras, $18,8 \%$ como muito abundante e comum, respectivamente, sendo ainda $6,2 \%$ considerada como dispersa. 
Segundo o método de Laroca e Mielke (1975) utilizado para o cálculo da dominância, $71,9 \%$ ou seja, 23 espécies foram dominantes e $25,0 \%$ são não dominantes.

Tabela 10 Distribuição percentual das espécies de besouros coprófagos capturados com armadilhas "pitfall", iscadas com fezes de bovinos, em área de mata, no periodo de 04-03-98 a 28-02-999, em Pedro Juan Caballero-Paraguai.

\begin{tabular}{|c|c|c|c|c|}
\hline \multirow[t]{2}{*}{ Índices faunisticos } & \multicolumn{2}{|c|}{ Classificação } & \multirow{2}{*}{$\begin{array}{c}\text { Total } \\
1\end{array}$} & \multirow{2}{*}{$\begin{array}{c}\% \\
3,1\end{array}$} \\
\hline & Super Freqüente & $(\mathrm{SF})$ & & \\
\hline \multirow[t]{4}{*}{ FREQÜÊNCIA } & Muito Freqüente & $(\mathrm{MF})$ & 7 & 21,9 \\
\hline & Freqüente & $(F)$ & 6 & 18,8 \\
\hline & Pouco Freqüente & (PF) & 18 & 56,2 \\
\hline & Super Abundante & (SA) & 1 & 3,1 \\
\hline \multirow[t]{6}{*}{ ABUNDÂNCIA } & Muito Abundante & (ma) & 6 & 18,8 \\
\hline & Abundante & (a) & 1 & 3,1 \\
\hline & Comum & (c & 6 & 18,8 \\
\hline & Dispersa & (d) & 2 & 6,2 \\
\hline & Rara & $(r)$ & 16 & 50,0 \\
\hline & Constante & $(W)$ & 11 & 34,4 \\
\hline \multirow[t]{3}{*}{ CONSTÂNCIA } & Acessória & $(Y)$ & 4 & 12,5 \\
\hline & Acidental & $(Z)$ & 17 & 53,1 \\
\hline & Super Dominante & (SD) & 1 & 3,1 \\
\hline \multirow[t]{2}{*}{ DOMINÂNCIA* } & Dominante & (D) & 23 & 71,9 \\
\hline & Não Dominante & (ND) & 8 & 25,0 \\
\hline $\begin{array}{l}\text { Total de espécies...... } \\
\text { Total de individuos.... } \\
\text { Índice de Diversidad } \\
\text { İndice de Diversidad }\end{array}$ & \multicolumn{2}{|c|}{ 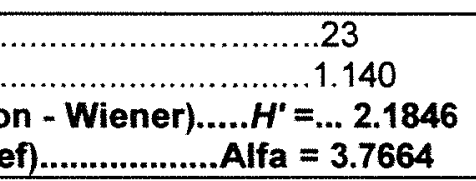 } & \multicolumn{2}{|c|}{ 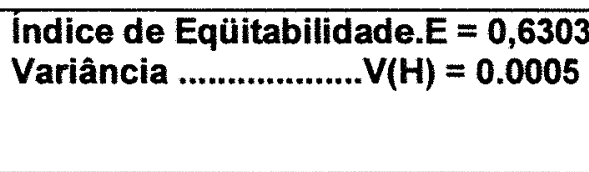 } \\
\hline
\end{tabular}

As espécies $O$. bucculus, E. caribaeus, Onthophagus sp.1 e 2, Onthophagus hirculus e Dichotomius carbonarius foram classificadas como, 
muito freqüente, muito abundante e dominante segundo o método de Laroca e Mielke (1975).

As espécies C. quinquemaculatus, C. septemmaculatus, E. plebejus foram classificadas como constantes, freqüentes, comuns e dominantes.

\subsection{2 Índice de diversidade.}

Os indices de diversidade $\alpha$ para cada local de coleta com os indivíduos coletados $(\mathrm{N})$, e número de espécies capturadas $(\mathrm{S})$ estão representados na tabela 11.

Tabela 11 Número de espécies (S), número de indivíduos $(\mathrm{N})$ e índice de diversidade $(\alpha)$, referente aos 3 locais de coleta dos coprófagos, no período 04-03-98 a 28-02-99m em Pedro Juan Caballero-Paraguai.

\begin{tabular}{lccc}
\hline \multicolumn{1}{c}{ Local } & S & N & $\alpha$ \\
\hline Mata & 32 & 3.754 & 3,766 \\
Pastagem & 33 & 2.238 & 4,149 \\
Semi-urbana & 23 & 1.142 & 3,12 \\
\hline
\end{tabular}

\subsection{3 Índice de similaridade.}

Os valores de indice de similaridade para os locais comparados, o número de espécies comuns ( $E C)$, o número de espécies coletadas (NE), quociente de similaridade (QS) e percentagem de similaridade (\%S) entre as áreas de coleta, encontra-se na Tabela 12.

A maior percentagem de similaridade foi obtida nas áreas de pastagem comparada a área semi-urbana. Vale dizer que entre esses locais teve maior número de espécies que concorrem tanto em um local como no outro e a menor 
$\%$ de similaridade $(21,6 \%)$ foi encontrada na comparação da área de mata em relação à área semi-urbana. No que diz ao quociente de similaridade, às áreas de pastagem e mata obtiveram um valor mais alto $(0,74)$ indicando que entre esses locais existe uma similaridade maior que as áreas de mata e semi-urbana $(0,54)$, o que indicou haver um menor número de espécies que concorrem simultaneamente em ambos locais.

Tabela 12 Determinação da percentagem de similaridade (\%S), quociente de similaridade (QS), espécies comuns (EC) para as áreas comparadas, e número de espécies (NE) para os coprófagos coletados em armadilhas "pitfall" iscadas com fezes de bovino, em 3 locais diferentes, no período de 04-03-98 a 28-02-99, em Pedro Juan Caballero-Paraguai.

\begin{tabular}{|c|c|c|c|c|}
\hline Locais & NE & EC & QS & $\% S$ \\
\hline Pastagem & 33 & & & \\
\hline Vs. & & 24 & 0,74 & 23,9 \\
\hline Mata & 32 & & & \\
\hline Pastagem & 33 & & & \\
\hline Vs. & & 19 & 0,67 & 54,3 \\
\hline Urbana & 23 & & & \\
\hline Mata & 32 & & & \\
\hline Vs. & & 15 & 0,54 & 21,6 \\
\hline Urbana & 23 & & & \\
\hline
\end{tabular}

\section{4 Índice de sinantropia}

O índice de sinantropia, calculado para todas as espécies, está representado no Tabela 13, e na Figura 9.

De acordo com o índice encontrado, as espécies de coprófagos coletadas estão localizadas nos diferentes niveis de adaptação, formando dessa maneira, 6 grupos diferenciados. 
Tabela 13 Índice de sinantropia, número de indivíduos e percentagem de participação em cada local dos coprófagos coletados em armadilhas "pitfall" iscadas com fezes de bovino no período de 0403-98 a 28-02-99 em Pedro Juan Caballero-Paraguai.

\begin{tabular}{|c|c|c|c|c|c|c|c|c|}
\hline № & Espécies & Pastagem & $\%$ & Urbana & $\%$ & Mata & $\%$ & Índice \\
\hline 1 & Aphodius sp. & 0 & 0 & 12 & 100 & 0 & 0 & 100 \\
\hline 2 & Canthon sp. & 0 & 0 & 1 & 100 & 0 & 0 & 100 \\
\hline 3 & Ataenius sp. 3 & 0 & 0 & 1 & 100 & 0 & 0 & 100 \\
\hline 4 & Diabroctis mimas & 0 & 0 & 1 & 100 & 0 & 0 & 100 \\
\hline 5 & Onthophagus ranunculus & 8 & 28,6 & 20 & 71,4 & 0 & 0 & 85,7 \\
\hline 6 & Ataenius sp. 1 & 241 & 31 & 525 & 67 & 15 & 2 & 80,5 \\
\hline 7 & Aphodius lividus & 65 & 54,2 & 54 & 45 & 1 & 0,8 & 71,1 \\
\hline 8 & Ataenius sculptor & 309 & 65,3 & 154 & 32,6 & 10 & 2,1 & 63,15 \\
\hline 9 & Ataenius sp. 2 & 123 & 52,7 & 99 & 41,6 & 16 & 6,7 & 61,25 \\
\hline 10 & Digitonthophagus gazella & 209 & 78 & 59 & 22 & 0 & 0 & 61 \\
\hline 11 & Ontherus sulcator & 423 & 75,4 & 19 & 3,4 & 117 & 20,9 & 60,35 \\
\hline 12 & Dichotomius bos & 46 & 83,6 & 9 & 16,4 & 0 & 0 & 58,2 \\
\hline 13 & Trichillum externepunctatum & 135 & 89,4 & 16 & 10,6 & 0 & 0 & 55,3 \\
\hline 14 & Gromphas lacordairei & 5 & 100 & 0 & 0 & 0 & 0 & 50 \\
\hline 15 & Dichotomius ascanius & 1 & 100 & 0 & 0 & 0 & 0 & 50 \\
\hline 16 & Ontherus sp.1 & 1 & 100 & 0 & 0 & 0 & 0 & 50 \\
\hline 17 & Dichotomius sp.1 & 1 & 100 & 0 & 0 & 0 & 0 & 50 \\
\hline 18 & Aphodius nigrita & 1 & 100 & 0 & 0 & 0 & 0 & 50 \\
\hline 19 & Canthon quinquemaculatus & 69 & 38,8 & 0 & 0 & 109 & 61,2 & 41,7 \\
\hline 20 & Canthidium barbacenicum & 19 & 95 & 0 & 0 & 1 & 5 & 42,5 \\
\hline 21 & Canthon lituratus & 33 & 91,7 & 0 & 0 & 3 & 8,3 & 37,55 \\
\hline 22 & Canthidium breve & 204 & 81,3 & 19 & 7,6 & 28 & 11,1 & 37,15 \\
\hline 23 & Ontherus appendiculatus & 3 & 60 & 1 & 20 & 1 & 20 & 30 \\
\hline 24 & Canthon curvodilataus & 19 & 51,3 & 1 & 2,7 & 17 & 46 & 17,65 \\
\hline 25 & Dichotomius nisus & 75 & 70,1 & 2 & 1,9 & 30 & 28 & 8,95 \\
\hline 26 & Onthophagus bucculus & 90 & 23,6 & 88 & 23,1 & 203 & 53,3 & $-18,4$ \\
\hline 27 & Canthon paraguayanum & 19 & 35,2 & 3 & 5,5 & 32 & 59,3 & $-36,2$ \\
\hline 28 & Coprafaneus jasius & 10 & 41,7 & 0 & 0 & 14 & 58,3 & $-37,5$ \\
\hline 29 & Onthophagus hirculus & 61 & 18,1 & 48 & 14,3 & 227 & 67,6 & $-44,3$ \\
\hline 30 & Canthon septemmaculatus & 37 & 30,8 & 4 & 3,4 & 79 & 65,8 & -47 \\
\hline 31 & Canthidium megathopoides & 1 & 33,3 & 0 & 0 & 2 & 66,7 & $-50,1$ \\
\hline 32 & Ontherus azteca & 2 & 18,2 & 0 & 0 & 9 & 81,8 & $-72,7$ \\
\hline 33 & Deltochillum sp. & 5 & 9,1 & 0 & 0 & 50 & 90,9 & 86,35 \\
\hline 34 & Onthophagus sp. 2 & 7 & 5 & 4 & 2,9 & 129 & 92,1 & $-86,7$ \\
\hline 35 & Dichotomius carbonarius & 7 & 2,5 & 0 & 0 & 270 & 95,5 & $-96,3$ \\
\hline 36 & Onthophagus sp.1 & 6 & 1,1 & 2 & 0,4 & 524 & 98,5 & $-97,6$ \\
\hline 37 & Eurysternus paralellus & 3 & 0,2 & 0 & 0 & 1537 & 99,8 & $-99,7$ \\
\hline 38 & Eurysternus caribaeus & 0 & 0 & 0 & 0 & 212 & 100 & -100 \\
\hline 39 & Eurysternus plebejus & 0 & 0 & 0 & 0 & 212 & 100 & -100 \\
\hline 40 & Cartwrightia cartwrighti & 0 & 0 & 0 & 0 & 8 & 100 & -100 \\
\hline 41 & Onthophagus sp. 3 & 0 & 0 & 0 & 0 & 8 & 100 & -100 \\
\hline 42 & Dichotomius sp.2 & 0 & 0 & 0 & 0 & 1 & 100 & -100 \\
\hline 43 & Dichotomius mormom & 0 & 0 & 0 & 0 & 1 & 100 & -100 \\
\hline 44 & Coprophaneus horus & 0 & 0 & 0 & 0 & 1 & 100 & -100 \\
\hline
\end{tabular}


Alta preferência por áreas densamente hahitadas

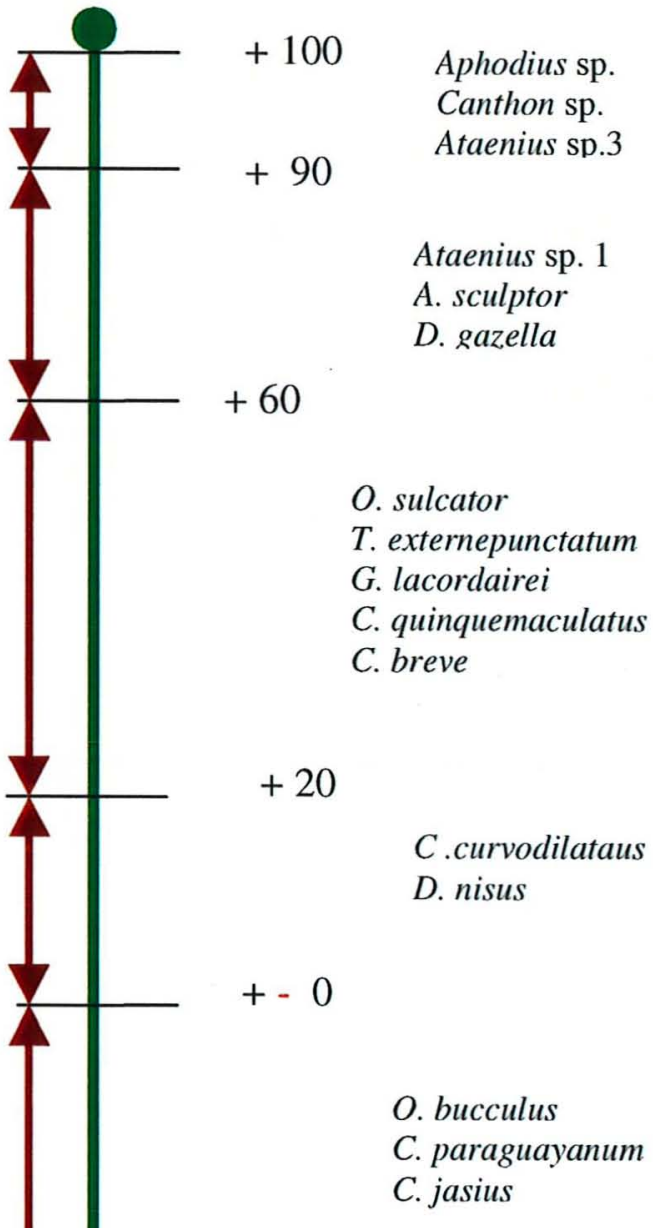

Independência por áreas habitadas

Preferência por áreas desabitadas

Completa ausência em áreas habitadas

Preferência por áreas habitadas

T. externepunctatum

. lacordaire

C. quinquemaculatus

breve
C. paraguayanum
C. jasius

Onthophagus sp. 1

Onthophagus sp. 2

O. hirculus

E. paralellus

E. caribaeus

E. plebejus

D. carbonarius

Figura 8 Índice de sinantropia para as espécies de coprófagos capturadas (algumas citadas), no período de 04-03-98 a 28-02-99, em 3 locais diferentes com armadilhas "pitfall" iscadas com fezes de bovinos, em Pedro Juan caballero - Paraguai. 
O primeiro $(9,1 \%)$ formado pelas espécies de Aphodius sp. Canthon sp, Ataenius sp. 3 e Diabroctis mimas mostraram uma alta preferência por áreas semi-urbanas; embora as 3 últimas espécies citadas foram capturadas somente um exemplar.

O segundo grupo correspondendo a $13,6 \%$ das espécies capturadas esta formado pelas espécies $O$. ranunculus, Ataenius sp.1 e sp.2, A lividus, $A$. sculptor, $D$. gazella, as que demonstraram uma alta preferência por áreas habitadas, variando seu índice de 85,7 a 61 .

No terceiro grupo, as que têm preferência por áreas habitadas representam $29,5 \%$ das espécies, entre as quais destacam-se $D$. bos, $T$. externepunctatum, G. lacordairei, $C$. quinquemaculatus e as espécies do gênero Canthidium: barbacenicum, lituratus e breve.

As espécies $C$. curvodilataus, $D$. nisus, mostraram independência por áreas habitadas e representam $0,45 \%$ das espécies, formando assim o quarto grupo dentro da classificação de preferências.

Os que têm preferências por áreas desabitadas, que formam o quinto grupo, com $6,8 \%$, são as seguintes espécies: 0 . bucclus, C. paraguayanum e C. jasius.

E por último, o sexto grupo, com $36,4 \%$, foram as que apresentaram uma completa ausência em áreas habitadas, variando o seu índice de $-44,25$ a -100 , formando assim as espécies denominadas assinantrópicas. Neste grupo destacam-se as espécies: Deltochillum sp., Onthophagus sp.2, D. carbonarius, Eurysternus paralellus, E. caribaeus e E. plebejus. 


\section{CONCLUSÕES}

- Foi capturada maior percentagem de paracoprídeos em relação aos endocoprideos e telecoprídeos nos três locais

- Nas 3 áreas de coleta, nos meses de maio a julho foram capturados menor número de espécies e de indivíduos.

- Os picos populacionais tanto em espécies como em indivíduos foram. verificados entre os meses de setembro a fevereiro, para os 3 locais de coleta.

- Temperaturas mais elevadas favorecem a captura-se de individuos e espécies.

- Precipitações até o nivel de $150 \mathrm{~mm}$ favorece a coleta de maior número de indivíduos e de espécies.

- O número de individuos encontrados na mata foi $68 \%$ superior ao da pastagem, embora os números de espécies nas 2 áreas sejam muito próximo.

- A área semi-urbana foi a que apresentou o menor número de espécies e de indivíduos. 
- Na pastagem as espécies Ontherus sulcator, Ataenius sculptor, Ataenius sp.1, Digitoonthophagus gazella, Canthidium breve, Trichillum externepunctatum foram as que apresentaram os maiores indices de dominância, abundância, freqüência e constância.

- Na mata a espécie Eurysternus paralellus foi considerada super dominante, super abundante, super freqüente e constante.

- Na mata as espécies do gênero Onthophagus: 0. sp.1, 0 . bucculus, 0 . hirculus e O. sp.2, alem de Dichotomius carbonarius, Eurystemus caribaeus e Ontherus sulcator foram as que apresentaram os maiores indices de dominância, abundância, freqüência e constância.

- Na área semi-urbana a espécie Ataenius sp.1 foi classificada como super dominante, super abundante, super freqüente e constante.

- Na área semi-urbana Ataenius sculptor, Ataenius sp.2, Onthophagus bucculus, Onthophagus hirculus e Digitonthophagus gazella foram as que apresentaram os maiores índices de dominância, abundância, freqüência e constância.

- O Indice de diversidade (Margalef) foi maior na pastagem em relação a mata e a semi-urbana.

- Maior percentagem de similaridade foi obtida quando comparadas a área de pastagem com a área semi-urbana.

- O indice de sinantropia evidenciou que as espécies Aphodius sp. Canthon sp. Ataenius sp. 3 e Diabroctis mimas estão adaptadas a presença humana. 


\section{REFERÊNCIAS BIBLIOGRÁFICAS}

ALVES, S.B. Biologia e importância econômica do Dichotomius anaglypticus (Mannerheim, 1829) (Coleoptera, Scarabaeidae). Piracicaba, 1977. 72p. Dissertação (Mestrado) - Escola Superior de Agricultura "Luiz de Queiroz", Universidade de São Paulo.

ALVES, S.B.; NAKANO, O Estudo da biologia do Dichotomius anaglypticus (Mannerheim, 1829) (Coleoptera, Scarabaeidae). Ecossistema, v.3, n.3, p.11-20, 1978.

AMAT-GARCIA, G. Patrones de distribución de escarabajos coprófagos (Coleoptera: Scarabaeidae) en relicto de bosque Altoandina, Cordillera Oriental de Colombia. Caldasia, v.19, n.1/2, p.191-204, 1999.

ANDUAGA, S.; HALFFTER G. Escarabajos asociados a madrigueras de roedores (Coleoptera : Scarabaeidae, Scarabaeinae). Folia Entomológica Mexicana, v.81, p.185-187, 1991.

ASSIS Jr., S.L.; ZANUNCIO, J.C.; VAZ-DE-MELLO; F.Z.; COURO, L.; MELIDO,R.C.N. Especificidade e preferência alimentar de besouros escarabeídeos (Coleoptera, Scarabaeidae) no Noroeste de Minas Gerais. In: REUNIÃO LATINO-AMERICANA DE SCARABAEOIDOLOGIA, 4., Viçosa, 1999. Resumos. Viçosa: UFV; EMBRAPA, 1999. p.74-76. 
BIANCHIN, I; ALVES, R.G.O; KOLLER, W.W. Efeito de carrapaticidas/Inseticidas "Pour-on" Sobre Adultos de Besouro Coprófago Africano Onthophagus gazella Fabr. (Coleoptera:Scarabaeidae). Anais da Sociedade Entomológica de Brasil, v.27, n.2, p.275-279, 1998.

BIANCHIN, I.; HONER, M.R.; GOMES, A.; KOLLER, W.W. Efeito de alguns carrapaticidas sobre Onthophagus gazella. Campo Grande: EMBRAPA, CNPGC. 1992. 7p.

BIERREGAARD Jr, R. O.; LOVEJOY, T.E.; KAPOS, V.; SANTOS, A.A. dos; HUTCHING, R.W. The biological dynamics of tropical rainforest fragments. A prospective comparison of fragments and continuous forest. BioScience, v.42, n.11, p. 859-866, 1992.

BRUSSAARD, L.; VISSER, W.J.F. Dung exploitation by the dung beetle Typheaus typhoeus (Col., Geotrupidae). Oecologia, v. 72, n.1, p.21-27, 1987.

BRYAN, R.P. The effects of dung beetle activity on the numbers of parasitic gastrointestinal helminth larvae recovered from pasture samples. Australian Journal of Agricultural Research, v.24, n.1, p.161-168, 1973.

BRYAN, R.P. The effects of dung beetle, Onthophagus gazella, on the ecology of the infective larvae of gastrointestinal nematodes of cattle. Australian Journal of Agricultural Research, v. 27, n.4, p.567-574, 1976.

BULMAN, G.M.; MUÑOZ COBEÑAS, M.E.; AMBRÚSTOLO, R.R.. EI impacto ecológico de las lactonas macrocíclicas (Endectocidas): una actualización comprensiva y comparativa. Veterinaria Argentina, v.13, n.127, p.2-16, 1996. 
CANO, E.B. Asociación de hábitat y potencial en monitoreo biológico de los Scarabaeinae (Coleoptera: Scarabaeidae) de la Reserva Bióesfera Maya, Petén, Guatemala. In: REUNIÃO LATINO-AMERICANA DE SCARABAEOIDOLOGIA, 4, Viçosa, 1999. Resumos: Viçosa: UFV; EMBRAPA, 1999. p.147-148.

DELGADO L, C.M. Diversidad de copronecrófagos (Coleoptera; Scarabaeidae) en cuatro estados sucesionales en la zona de influencia del Proyecto Hidroeléctrico Porce II (Antioquia - Colombia). In: REUNIÃO LATINOAMERICANA DE SCARABAEOIDOLOGIA, Viçosa, 4., 1999. Resumos. Viçosa: UFV EMBRAPA, 1999. p.149-150.

DOUBE, B.M. A funcional classification for analysis of the structure of dung beetle assemblages. Ecological Entomology, v 15, p.371-383, 1990.

DOUBE, B.M.; GILLER, P.S.; MOOLA, F. Dung burial strategies in some South African Coprine and dung beetles (Coleoptera, Scarabaeidae). Ecological Entomology, v.13, n. 3, p.251-261, 1988.

DOUBE, B.M; MACQUEEN, A.; FAY, H.A.C. Effects of dung fauna on survival and size of Buffalo flies (Haematobia spp.) Breeding in the field in Sout Africa and Australia. Jouranl of Applied Ecology, v.25, p.523-536, 1988.

DUDLEY, C.O. Insects of the floodplain. 3. The dung beetles of the western grasslands of the Chilwa area. Monographiae Biologicae, v. 35, p.285290, 1979.

EDWARDS, P.B. Phenology and field biology of the dung beetle Onitis caffer Boheman (Coleoptera: Scarabaeidae) in sourthen Africa. Bulletin Entomological Research, v.76, p.433-445, 1986. 
EDWARDS, P.B. Field ecology of a brood-caring dung beetle Kheper nigroaeneus habitat predictability and life history strategy. Oecologia, v.75, p.527-534, 1988.

EDWARDS, P.B.; ASCHENBORN, H.H. Patterns of nesting and dung burial in Onitis dung beetles: implications for pasture productivity and fly control. Journal of Applied Ecology, v.24, n.3, p.837-851, 1987.

EDWARDS, P.B.; ASCHENBORN, H.H. Maternal care of a single offspring in the dung beetle Kepper nigroaeneus: The consequences of extreme parental investiment. Journal of Natural History, n.23, p.17-27, 1989.

ESCOBAR, F. Comparación de la diversidad de escarabajos del estiércol en dos escalas espaciales en la Cordillera Oriental, Andes de Colombia. In: REUNIÃO LATINO-AMERICANA DE SCARABAEOIDOLOGIA, 4., Viçosa. 1999 Resumos. Viçosa: UFV;EMBRAPA, 1999. p.74-76.

ESTRADA, A.; COATES-ESTRADA, R. Howler monkeys (Alowata palliata), dung beetles (Scarabaeidae) and seed dispersal: ecological interactions in the tropical rain forest of Los Tuxtlas, Mexico. Journal of Tropical Ecology, n.7, p.459-472, 1991.

FAVILA, M.E. Comportamiento durante el período de maduración gonadica en un escarabajo rodador (Coleoptera: Scarabaeidae; Scarabaeinae). Folia Entomológica Mexicana, v.76, p. 55-64, 1988.

FAZOLIN, M. Análise faunistica de insetos coletados com armadilha luminosa em seringueira no Acre. Piracicaba, 1991. 236 p. Tese (Doutorado) - Escola Superior de Agricultura "Luiz de Queiroz", Universidade de São Paulo. 
FINCHER, G.T. Dung beetles as biological control agents por gastrointestinal parasites of Livestock. The Journal of Parasitology, v.59, n.2, p.396-399, 1973.

FINCHER, G.T. Effect of dung beetle activity on the number of nematode parasites acquired by grazing cattle. The Journal of Parasitology, v.61, n.4, p.759-762, 1975.

FINCHER, G.T. The potencial value of dung beetles in pasture ecosystems. Journal Georgia Entomologycal Society. v.16, suppl. 1, p.317-332, 1981.

FINHER, G.T.; HUNTER III, J.S. Overwintering studies on Onthophagus gazella (F.) and Onthophagis bonasus (F.) in two different textural classes of soil in East-Central, Texas. Southwestern Entomologist, v.14, n.2, p.133-138, 1989.

FINCHER, G.T.; STEWART, T.B.; DAVIS, R. Atraction of coprofagous beetles to feces of various animals. The Journal of Parasitology, v.56, n.2, p.378$383,1970$.

FLECHTMANN, C.A.H.; RODRIGUES, S.R. Insectos fimícolas associados a fezes bovinas em Jaraguá do Sul/SC. 1. Besouros coprófagos (Coleoptera, Scarabaeidae). Revista Brasileira de Entomologia, v.39, n.2, p.303-309, 1995.

FLECHTMANN, C.A.H.; RODRIGUES, S.R.; SENO, M.C..Z. Controle biológico da mosca-dos-chifres (Haematobia irritans irritans) em Selvíria/MS, Mato Grosso do Sul. 1. Metodologia de estudo e seleção de fauna fimícola de insetos. Revista Brasileira de Entomologia, v.39, n.1, p.1-11, 1995. 
FLECHTMANN, C.A.H.; RODRIGUES, S.R.; ARAÚJO, S.D.; WENZEL, R.L. Levantamento de insetos fimícolas em llha Solteira, São Paulo, Brasil. Revista Brasileira de Entomologia, v.39, n.1, p.115-120, 1995.

FLECHTMANN, C.A.H.; RODRIGUES, S.R.; KOLLER, W.W.; AIDAR, T.; CORREA, A.M.; SILVA, J.C.C.; BALTA, O.S.; OLIVEIRA, J.M.; OLIVEIRA, V.L. Coleópteros coprófagos em armadilhas "pitfall" (alcapão) em Aquidauana - MS. (Resultados Preliminares). In: CONGRESSO PANAMERICANO DE CIÊNCIAS VETERINÁRIAS, 15, Campo Grande 1996. Resumos. Campo Grande: SOMVET; CRMV/MS, 1996. p.304.

GALBIATI, C.; BENSI, C.; COSTA CONCEIÇÃO, C.H.; FLORCOVSKI, J.L.; CALAFIORI, M.H. Estudo comparativo entre besouros do esterco, Dichotomius anaglypticus (Mann., 1829) e Onthophagus gazella (F.), sobre as pastagens, em condições Brasileiras. In: CONGRESSO DE ENTOMOLOGIA, 15., Caxambú, 1995. Resumos. Caxambú, MG: 1995, p.191.

GALBIATI, C.; COSTA CONCEIÇÃO, C.H.; FLORCOVSKI, J.L.; CALAFIORI, M.H.; TOBIAS, A.T. Efeito de vermífugos injetáveis em bovino de leite sobre besouro coprófago, Dichotomius anaglypticus (Mann., 1829). In: CONGRESSO DE BRASILEIRO DE ENTOMOLOGIA, 15, Caxambú: SEB, 1995. Resumos. Caxambú, MG: 1995. p.192.

GUILLER, P.S.; DOUBE, B.M. Experimental analysis of inter and intaespecific competition in dung beetle communities. Journal of Animal Ecology, v.58, n.1, p.129-142, 1989.

GUIMARÃES, J.A.; MENDES J. Succesion and ábundance os Staphylinidae in cattle Dung in Uberlândia, Brazil. Memorias do Instituto Oswaldo Cruz, v. 93, n.1, p.127-131, 1998. 
HALFFTER, G. Historical and ecological factors determining the geografical distribution of beetles (Coleoptera: Scarabaeidae: Scarabaeinae). Folia Entomologica Mexicana, v.8, p.194-241, 1991.

HALFFTER, G.; EDMONS, W.D.. The nesting behavior of dung beetles (Scarabaeinae): ecological and evolutive approach. Publs., Mexico: Instituto de Ecologia, 1982, 176 p. (Publications, 10).

HALFFTER, G.; MATTHEWS, E.G. The natural history of dung beetles, of the sub-family Scarabaeinae (Coleoptera, Scarabaeidae). Folia Entomologica Mexicana, v.12/14, 312p, 1966.

HALFFTER, G.; HUERTA, C.; LOPEZ-PORTILLO, J. Parental care and offspring survival in Copris incertus Say, a sub-social beetle. Animal Behavior, v.52, p.133-139, 1996.

HANSKI, I. The community of coprofagous beetles (Coleoptera, Scarabaeidae and Hydrophilidae) in northern Europe. Annals Entomology Fennicia, v.46, n.3, p.57-73, 1980.

HANSKI, I; CAMBERFORT, Y. Dung beetle ecology. New Jersey: Princeton Univiversity Press. New Jersey. 1991, 481p.

HARRIS, R.L.; ONAGA, K.; BLUME, R.R.; ROTH, J.P.; SUMMERLIN, J.W. Survey of beneficial insects in Undisturbed Cattle Droppings on Oahu, Hawaii. Proceedings, Hawaiian Entomologycal Society, v.24, n.1, p.91$95,1982$.

HEINRICH, J.E.; BARTHOLOMEW, G.A. The ecology of the african dung beetle. Scientific American, v.24, n.5, p.118-126, 1979. 
HOFFMANN, M.A. A importância do besouro vira-bosta para a pecuária. Agricultura Biodinâmica. (IBD). Instituto Biodinâmico de Desenvolvimento Rural. v.15, n.80, p.32-33, 1998.

HOLTER, P. Abundance and reproductive strategy of dung beetle Aphodius rufipes (L.) (Scarabaeidae). Ecological Entomology, v.4, n.4, p.317-326, 1979.

HUERTA, C.; ANDUAGA, S.; HALFFTER, G. Relaciones entre nidificación y ovario en Copris (Coleoptera, Scarabaeidae, Scarabaeinae). Folia Entomológica Mexicana, v. 47, p.139-170, 1981.

JANZEN, D.H. Seasonal change in abundance of large nocturnal dung beetles (Scarabaeidae) in Costa Rica diciduos foerst and adjacent horse pasture. Oikos, v.41, p.402-410, 1982.

KEY, R.S. Cluster analysis of dung inhabiting beetle comunities from different altitudes in Jostedalen, Sout-West Norway. Fauna Novergica. Norwegian Journal of Entomology, Series B, v.29, p.24-33, 1982.

KIRK, A.A. Dung beetles (Coleoptera: Scarabaeidae) active in patchy forest and pasture habitats in Santa Cruz Province, Bolivia, During Spring. Folia Entomológica Mexicana, v.84, p.45-54, 1992.

KIRK, A.A.; WALACE, M.M.H. Seasonal variations in numbers, biomass and breeding patterns of dung beetles (Coleoptera: Scarabaeidae) in Southern France. Enthomophaga, v.35, n.4, p.569-581, 1990.

KLEIN, B.C. Effects of forest fragmentation on dung and carrion beetle commnities in central Amazonia. Ecology, v.70, n.6, p.1715-1725, 1989. 
KLEMPERER, H.G. Subsocial behavior in Oniticellus cinctus (Coleoptera, Scarabaeidae): effect of the brood on parental care and oviposition. Physiological Entomology, v.8, p.393-402, 1983.

KLEMPERER, H.G. The evolution of parental behavior in Scarabaeinae (Coleoptera, Scarabaeidae): an experimental approach. Ecological Entomology, v.8, p. 49-59, 1993.

KOLLER, W.W. Parceiros biológicos na pecuária. Campo Grande: EMBRAPA, Gado de Corte, 1998. 6p. (Gado de Corte Divulga, 28).

KOLLER, W.W.; GOMES, A.; FLECHTMANNN, C.A.H.; RODRIGUES, S.R.; BIANCHIN, I.; HONER, M.R. Ocorrência e sazonalidade de besouros copro/necrófagos (Coleoptera; Scarabaeidae), em massas fecais de Bovinos, na Região de Cerrados do Mato Grosso do Sul. Campo Grande EMBRAPA, CNPGC, 1997. 5p. (EMBRAPA.CNPGC Pesquisa em Andamento, 48).

KOLLER, W.W.; GOMES, A.; RODRIGUES, S.R. \& FLECHTMANNN, C.A.H. Scarabaeidae coprófagos, em Campo Grande, MS. In ENCONTRO REGIONAL DE BIÓLOGOS DO CRB-1 (SP, MT, MS), Campo Grande; 1998. Resumos. Campo Grande: CRB-1; UFMS, 1998. p.60.

KRUESS, A.; TSCHARNTKE, T. Habitat fragmentation, species loss, and biological control. Science, v.264, p.1581-1587, 1994.

LAURENCE, W.F; LAURENCE, S.G.; FERREIRA, L.V.; RANKIN-DE-MERONA, J.M.; GASCON, C.; LOVEJOY, T.E. Biomass collapse in amazonian forest fragments. Science, v.278, p.1117-1118, 1997. 
LOBO, J.M.; SANMARTIN, I.; MARTIEN-PIERA, F. Diversity and spatial turnover of dung beetle (Coleoptera: Scarabaeoidea) communities in a protected area of South Europe Huelva, Spain, v.11, 71-88, 1997

LOPEZ, P.P.; LOUZADA, J.N.C.; VAZ-DE-MELLO, F.Z. Reconstrução da comunidade de Scarabaeidae em áreas de regeneração de vegetação. In: REUNIÃO LATINO-AMERICANA DE SCARABAEOIDOLOGIA, 4., Viçosa 1999, Resumos. Viçosa: UFV; EMBRAPA, p.74-76.

LOUZADA, J.N.C. Considerations on the perching behavior of tropical dung beetles (Coleoptera, Scarabaeidae). Revista Brasileira de Entomologia, v.41, n.2/4, p.125-128, 1998.

LUDWIG, J.A.; REYNOLS, J.F. Statistical ecology: a primer on methods and computing. New York: John Wiley, 1988. 337 p.

LUEDERWALDT, H. Biologia de varias espécies de Pinotus de São Paulo. Revista do Museu Paulista, v.9, p.365-366, 1914.

LUMARET, J.P.;. KADIRI, N.; BERTRAND, M. Changes in resource: consequences for the dynamics of dung beetle communities. Journal of Applied Ecology, v.29, p.349-356, 1992.

LUMARET, J.P.; KIRK, A. Ecology of dung beetles in the french mediterraneam regiom (Coleoptera: Sacarabaeidae). Acta Zoológica Mexicana, v.24, p.1$55,1987$. 
MARCHINI, L.C.; RUIZ DÍAZ, M.A.; RODRIGUES, S.R.; SILVEIRA NETO, S. Atratividad de besouros coprófagos (Coleoptera: Scarabaeidae) por diferentes tipos de fezes. In: CONGRESSO BRASILEIRO DE ENTOMOLOGIA, 17, Rio de Janeiro, 1998. Resumos Rio de Janeiro; SEB, 1998. p.838.

MARTINEZ M., I. Datos sobre la biologia y la reproducción en Aphodiinae (Coleoptera: Scarabaeidae): Revisión. In: REUNIÃO LATINO-AMERICANA DE SCARABAEOIDOLOGIA, 4., Viçosa, 1999 Resumos. Viçosa: UFV; EMBRAPA, 1999. p.27-34.

MARTINEZ M., I.; MONTES E. O. de, E. T. Observaciones sobre algunos factores microambientales y el ciclo biológico de dos espécies de escarabajos rodadores (Coleoptera, Scarabaeidae, Canthon). Folia Entomolologica Mexicana, v.91, p.47-59, 1994.

MERRIT, R.W.; ANDERSON, J.R. The effects of different pasture and droppings. Hilgardia, v.45, n.2, p.31-71, 1977.

MIRANDA, C.H.B.; NASCIMENTO, Y.A; BINCHIN, I. Desenvolvimento de um programa integrado de controle dos nematódeos e a mosca-dos-chifres na Região dos Cerrados: Fase 3: potencial de Onthophagus gazella no enterrio de Fezes Bovinas. Campo Grande: EMBRAPA, CNPGC, 1990. 5p. (EMBRAPA. CNPGC Pesquisa em Andamento, 42).

MOHR, C.O. Cattle droppings as ecological units. Ecological Monagraphs, v.13, p.275-298, 1943. 
MONTES, E.O. de; MARTÍNEZ, I.; CRUZ, M.; FAVILA, M.E. Observaciones de campo sobre el comportamiento y madurez gonadica en Canthon indigaceus chevrolati Harold (Coleoptera: Scarabaeidae). Folia Entomológica Mexicana, v.83, p.69-86, 1991.

MYRCHA, A.; ANDRZEJEWSKA, L. Biogenergetics of the developmental period of the coprophagous beetle of Panamanian pastures. Ekologia Polaska, v.31, n.2, p.219-244, 1984.

NAVARRETE-HEREDIA, J.L.; GALINDO M., N.E. Escarabajos asociados a Basidiomycetes en San José de los Laureles, Morelos, México (Coleoptera: Scarabaeidae). Folia Entomológica Mexicana, v.99, p.1-16, 1997.

NUORTEVA, P., Synanthropy of blowflies (Dip., Calliphoridae) in Finland. Annals Entomology Fennicia, v. 9, p.1-49, 1963.

ODUM, E.P. Ecologia: Guanabara Kogan,1988, 434p.

PECK, S.B.; FORSYTH, A. Composition, sructure, and competitive behaviour in a guild of Ecuatoriam rain forest dung beetles (Coleoptera; Scarabaeidae). Canadian Journal of Zoology, v.60, n.7, p.1624-1634, 1982.

PRATISSOLI, D.; BRAZ TORRES, J. Susceptibilidade de Onthophagus gazella (F.) (Coleoptera: Scarabaeidae) a Carrapaticidas e Herbicidas na Fase de Nidificação. Revista Ceres, v.45, n.259, p. 245-253, 1998.

RIDSDILL-SMITH, T.J. Selecting new kinds of dung beetles for better bush fly control. Journal of Agriculture of Western Australia, v.25, n.30, p. 108$110,1984$. 
RIDSDILL-SMITH, T.J. The effect of seasonal changes in cattle dung on egg production by two species of dung beetles (Coleoptera: Scarabaeidae) in sout western Australia. Bulletin of Entomological Research, v.76, n.1, p.63-68, 1986.

RIDSDILL-SMITH, T.J.; HAYLES, L. Stages of bush fly, Musca vetustissima (Diptera: Muscidae), killed by scarabaeinae dung beetles (Coleoptera: Scarabaeidae) in unfavourable cattle dung. Bulletin of Entomological Research, v.80, n.4, p.473-478, 1990.

RIDSDILL-SMITH, T.J.; KIRK, A.A., Dung beetles and dispersal catle dung. Proc. 3rd. Australian Conf. GrassI. Invert. Ecol., Adelaide, 1981, (K.E. Lee, Ed.). S.A. Govt. Printer, Adelaide, p.215-219, 1982.

RIVERA-CERVANTES, L.E.; GRACIA-REAL, E. Análisis preliminar sobre la composición de los escarabajos necrófilos (Coleoptera: Silphidae y Scarabaeidae) presentes en dos bosques de Pino (uno dañado por el fuego), en la Estación Científica Las Joyas, Sierra de Manatlan, Jalisco, México. Dugesiana, v.5, n.1, p.11-22, 1998.

RODRIGUES, L.R.A. Os besouros coprófagos no ecossistema das pastagens. O Estado de São Paulo, 03 out. 1984.

RODRIGUES, L.R.A. Aspectos comportamentais dos besouros coprófagos em pastagens. In: ENCONTRO PAULISTA DE ETOLOGIA, 3, Ribeirão Preto, 1985. Anais. Ribeirão Preto: AZESP, 1985. p. 95-103.

RODRIGUES, L.R.A. Os besouros coprófagos em pastagens. In: SIMPÓSIO SOBRE ECOSSISTEMAS PASTAGENS, Jaboticabal, 1989. Anais. Jaboticabal: FUNEP, 1989. p.97-133. 
RODRIGUES, S.R. Ocorrência de besouros coprófagos e avaliações microclimáticas em massas fecais de bovinos, visando ao controle biológico de Haematobia irritans (Linné, 1758) (Diptera; Muscidae) em Piracaba/SP. Piracicaba, 1966. 87p. Dissertação (Mestrado) - Escola Superior de Agricultura "Luiz de Queiroz", Universidad de São Paulo.

RODRIGUES, S.R.; FLECHTMANN, C.A H. Comparação da fauna de besouros Coprófagos em área de mata ciliar, de transição e de pastagem em Selvíria/MS. Resultados preliminares. In: CONGRESO BRASILEIRO DE ENTOMOLOGIA, 14, Piracicaba, 1993. Resumos. Piracicaba: SEB, 1993, p.134.

RODRIGUES, S.R.; FLECHTMANN, C.A H. Aspectos biologicos de Canthon lituratus (Germar, 1813) e Canthidium megathopoides Boucomont, 1928 (Coleoptera, Scarabaeidae). Acta Zoolológica Mexicana, n.70, p.1-12, 1997.

RODRIGUES, S.R.; FLECHTMANNN, C.A H. Besouros coprófagos (Coleoptera, Scarabaeidae) em Pastagem em Irati/PR. In: CONGRESO BRASILEIRO DE ENTOMOLOGIA, Caxambú, 1995. Resumos. Caxambú: SEB, 1995, p. 581.

RODRIGUES, S.R.; MARCHINI, L.C. Besouros coprófagos (Coleoptera; Scarabaeidae) coletados em Piracicaba/SP. In: SIMPÓSIO DE CONTROLE BIOLÓGICO, 5. Foz do Iguaçu, 1996. Anais. Foz do Iguaçu: 1996, p.420.

ROTH, J.P. Compatibility of coprofagous scarabs and fimicolous staphylinids as biological control agents of the horn fly, Haematobia irritans (L.) (Diptera: Muscidae). Environmental Entomology, v.12, n.1, p.124-127, 1993. 
RUIZ DIAZ V., M.A.; LAJARTHE C, A.M.; BENITEZ N, M.C.; KAWATA Y., N..K; NARA T., F. Multiplicación y distribución de Otonthophagus gazella y levantamiento de especies de coleópteros nativos del Paraguay. Pedro Juan Caballero: Universidad Nacional de Asunción, Facultad de Ciencias Agrarias, Dpto. de Protección Vegetal División Entomologia. Pedro Juan Caballero, 1995. 23p. (Boletin Divulgativo).

RUIZ DIAZ V., M.A.; MARCHINI, L.C.; RODRIGUES, S.R. \& SILVEIRA NETO, S. Horário de atividade de besouros coprófagos (Coleoptera, Scarabaeidae em área de pastagem e mata. In: REUNIÃO LATINO-AMERICANA DE SCARABAEOIDOLOGIA, 4., Viçosa, 1999. Resumos: Viçosa: EMBRAPA, 1999 p.68-69.

RUIZ DIAZ V., M.A.; MARCHINI, L.C.; RODRIGUES, S.R. \& SILVEIRA NETO, S. Besouros coprófagos (Coleoptera: Scarabaeidae) ocorrentes em diferentes ambientes. In: CONGRESSO BRASILEIRO DE ENTOMOLOGIA, 17, Rio de Janeiro, 1998. Resumos Rio de Janeiro; SEB, 1998. p.915

SATO, H.; IMAMORI, M. Nesting behavior of a subsocial African ball-roller Kheper platynotus (Coleoptera, Scarabaeidae). Ecological Entomology, v.12, p.415-425, 1987.

SHEPHERD, V. E; CHAPMAM, C.A. Dung beetles as secondary seed dispersers: Impact on seed predation and germination. Journal of Tropical Ecology, v.14, n.2, p.199-215, 1988.

SILVEIRA NETO, S.; NAKANO, O.; BARBIN, D.; NOVA, N.A.V. Manual de ecologia dos insetos. São Paulo: Ceres, 1976. 419p

TALLAMAY, D.W.; WOOD, T.K. Convergence patterns in subsocial insects. Annual Review of Entomology, v.31, p.369-390, 1984. 
TERRON, R.A.; ANDUAGA, S.; MORON, M.A. Análisis de la Coleopterofauna Necrofila de la Reserva de la Biosfera "La Michilia", Durango, México. Folia Entomológica Mexicana, v.81, p.315-324, 1991.

TYNDALE-BISCOE, M. Physiological age-grading in females of the dung beetle Euoniticellus intermedius (Reiche) (Coleoptera: Scarabaeidae). Bulletin of Entomological Research, v.68, p.207-217, 1978.

TYNDALE-BISCOE, M. Adaptative significance of brood care of Copris diversus Waterhouse (Coleoptera: Scarabaeidae). Bulletin of Entomological Research, v.74, p.453-461, 1984.

TYNDALE-BISCOE, M.; WALLACE, M.M.H.; WALKER, J.M. An ecological study of na australian dung beetle, Onthophagus granulatus Boheman (Coleoptera: Scarabaeidae), using physiological age-grading techniques. Bulletin of Entomological Research, v.71, n.1, p.137-152, 1981.

UNIVERSIDAD NACIONAL DE ASUNCION, Facultad de Ciencias Agrarias, Atlas ambiental de la Region Oriental del Paraguay. San Lorenzo Cooperación Técnica de la República Federal de Alemania, (CIF/FCA/GTZ), 1995 v.2, 62p.

WATERHOUSE, D.F. The biological control of dung. Scientific American, v.230, n.4, p.100-109, 1974.

VAZ-DE-MELLO, F.Z. Scarabaeidae do Estado de Roraima, Brasil. In: REUNIÃO LATINO-AMERICANA DE SCARABAEOIDOLOGIA, 4., Viçosa, 1999. Resumos. Viçosa: EMBRAPA 1999 p.78-79. 
VAZ-DE-MELLO, F.Z.; LOUZADA, J.N.C.; FALQUETO, S.A; SCHOEREDER, J.H.; LIMA, E. Scarabaeoidea Laparosticti de Viçosa, Minas Gerais, Brasil. In: REUNIÃO LATINO-AMERICANA DE SCARABAEOIDOLOGIA, 4., Viçosa, 1999. Resumos. Viçosa: EMBRAPA, 1999. p.77-78. 